\title{
A ESCRAVIDÃo E O ACESSO À TERRA NAS CONCEPÇÕES DE Luís Antônio de Oliveira Mendes (1792-1821)
}

\author{
Magnus Roberto de Mello Pereira (iD
}

Universidade Federal do Paraná

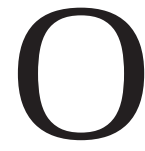
advogado luso-brasileiro Luís Antônio de Oliveira Mendes nasceu na Cidade da Bahia, em 1748. Estudou Direito na Universidade de Coimbra e, depois de graduado, radicou-se em Lisboa, onde advogou por mais de quatro décadas. Por fim, voltou a sua Salvador natal. Costuma ser lembrado por ter escrito um conhecido ensaio sobre as doenças que acometiam os escravos no tráfico entre a África e o Brasil, no qual a melancolia do cativeiro, o banzo, foi caracterizada pela primeira vez. O que a historiografia brasileira registra sobre sua vida não vai muito além disso, apesar de ter sido um dos mais fecundos autores brasileiros do período que antecedeu a Independência. Se não é um homem de letras de todo ignorado é porque parte de sua produção acadêmica ainda é estudada. No entanto, o autor propriamente dito permanece um ilustre desconhecido. Nesse aspecto, não é uma exceção, pois os historiadores brasileiros vêm utilizando com frequência a obra legada pelos letrados do período, mas de forma inespecífica, no mais das vezes em citações com o intuito de descrever alguma vila, ilustrar as atividades econômicas da época ou ressaltar os costumes do passado de uma dada região do país. Documentação tomada como repertório de informações, sem atentar para a autoria ou o contexto em que foi produzida.

Na década de 1950, na apresentação de um dos textos de Oliveira Mendes, publicado como de autor desconhecido, o editor simplesmente 
trocou o nome de seu estudo de Discursos preliminar, histórico, introdutivo com natureza de descrição econômica da Comarca e Cidade do Salvador para Aspectos da economia colonial. ${ }^{1}$ Além do que, o mesmo editor supôs a "vinculação do autor aos quadros rurais ou agroindustriais; ou a sua nacionalidade lusitana". ${ }^{2}$ Nem uma coisa nem outra se aplica a Mendes. Enganos dessa natureza demonstram a dificuldade que os historiadores tinham, e ainda têm, para compreender o quadro mental dos intelectuais luso-brasileiros das décadas finais do período colonial. ${ }^{3}$

Assim como ocorreu com uma parcela significativa dos filhos da elite brasileira enviados para estudar em Coimbra na virada do século XVIII para o XIX, Oliveira Mendes foi envolto em uma aura de esquecimento. Isto não se deu por acaso, mas porque a historiografia republicana sobre o período foi concebida a partir de princípios nacionalistas, que transformaram a Independência do Brasil em um fato absoluto e inelutável. De acordo com Silvia Hunold Lara, foram Holanda, Prado Jr. e Freyre os principais responsáveis pela consolidação do paradigma, até hoje predominante, segundo o qual a colônia é entendida como um estágio prévio que precede a nação e é esta - o Brasil independente - que lhe confere inteligibilidade. ${ }^{4}$ Por conseguinte, ser partidário da indepen-

1 Manoel Pinto de Aguiar (ed.), Aspectos da economia colonial, Salvador: Livraria Progresso, 1957.

2 Pinto de Aguiar, Aspectos, p. 4.

3 O uso da palavra intelectual, para se referir aos homens de letra do período, quase sempre é reputada como uso anacrônico de um jargão sociológico contemporâneo. Quero argumentar que há um profundo equívoco nessa avaliação. Já dizia a Nouvelle Géographie, de 1798, que na Rússia "ne manquoit nullement des intellectuels" (grifo nosso), referindo-se exatamente aos integrantes das academias, tal qual nosso caso. Como se observa, a palavra intelectual (intellectuel) para designar os savans, philosophes ou hommes de letres já estava em uso no final do século XVIII. Não se trata, portanto, de um anacronismo, nem de um jargão sociológico recente. É apenas uma palavra corrente, há muito usada para designar os integrantes desse grupo social. Ver William Guthrie (ed.), Nouvelle Géographie, Universelle, Descriptive, Historique, Industrielle et Commerciale des Quatre Parties du Monde, Paris: Langlois, 1798, v. 1, p. 236.

4 Sílvia Hunold Lara, “Conectando historiografias: a escravidão africana e o Antigo Regime na América portuguesa” in Maria F. Bicalho e Vera Lúcia A. Ferlini (orgs.), Modos de governar: ideias e práticas políticas no Império português, séculos XVI-XIX (São Paulo: Alameda, 2005), pp. 21-38. 
dência passou a ser uma exigência extemporânea. No entanto, se dentre os luso-brasileiros que estudaram em Coimbra saíram muitos dos que vieram a acalentar expectativas independentistas, também é verdade que a parcela mais expressiva desses intelectuais esteve perfeitamente afinada com as políticas metropolitanas. ${ }^{5}$

As trajetórias de praticamente todos esses colonos ilustrados se deram sob os auspícios régios e eles se consideravam "portugueses da América”, leais súditos da Coroa, diretamente envolvidos na concepção de um "Grande Império", no qual coubesse às elites coloniais uma fatia de poder. ${ }^{6}$ Muitos deles, como o mineralogista José Bonifácio de Andrada e Silva, tornaram-se partidários da independência tão somente no apagar das luzes do primeiro Império colonial português. Até onde é possível saber, Oliveira Mendes ainda se demonstrava partidário da união BrasilPortugal quando da convocação das Cortes de 1821. Para a historiografia nacionalista, a vinculação de muitos intelectuais luso-brasileiros com os projetos imperiais portugueses tornava-os traidores de uma nação que ainda não existia. Por exemplo, diriam sobre Alexandre Rodrigues Ferreira que, “apesar de ter, como nascido na colônia, pago um preço não pequeno à odiosa ordem maniqueísta do mundo colonial, o naturalista curva-se e serve". ${ }^{7}$ Aqueles que não foram partidários precoces do independentismo tiveram suas biografias obscurecidas, as de outros foram ajustadas a propósito pelo nacionalismo historiográfico da época. ${ }^{8}$

5 Sobre a questão, ver Magnus Roberto de Mello Pereira e Ana Lúcia Rocha Barbalho da Cruz, "A história de uma ausência: os colonos cientistas da América portuguesa na historiografia brasileira” in João Fragoso et al., Nas rotas do Império, 2a ed. (Vitória: Edufes, 2014), pp. 342-343.

6 Nesse sentido, o trabalho da historiadora Maria de Lourdes Viana Lyra trouxe um contributo original para se pensar a permanência da ideia de Império, entre as elites políticas do Brasil, mesmo após a emancipação da colônia. Maria de Lourdes Viana Lyra, A utopia do poderoso império, Rio de Janeiro: Sete Letras, 1994.

7 Carlos de Araújo Moreira Neto, "Introdução” in Alexandre Rodrigues Ferreira, Viagem filosófica ao Rio Negro, (Belém: Museu Paraense Emílio Goeldi, 1983), p. 36.

8 Ver como a biografia de João da Silva Feijó, outro acadêmico luso-brasileiro da época, foi sendo adaptada ao longo do tempo em Magnus Roberto de Mello Pereira, “João da Silva [Feijó?]: a trajetória de um homem de ciências luso-brasileiro” in Magnus 
Isto posto, para entender um autor como Oliveira Mendes, assim como diversos outros intelectuais luso-brasileiros do período, é necessário devolvê-lo à sua origem familiar e ao universo de sua formação intelectual, da qual fez parte a Universidade de Coimbra e a Academia Real das Ciências de Lisboa.

\section{As origens}

Diversamente do que ocorreu com a maior parte dos estudantes baianos mandados a Coimbra, a família de Luís Antônio de Oliveira Mendes Dias Lobato não pertencia aos altos estratos da tradicional elite latifundiária regional. Seu avô paterno era o afamado mestre construtor português Felipe de Oliveira Mendes, responsável pelo projeto e pela edificação de diversas igrejas de Salvador, como a de Santana e do Pilar. Seu filho, Manoel de Oliveira Mendes, estudou no colégio jesuíta do Terreiro de Jesus, onde obteve grau de licenciado e de mestre em ciências. ${ }^{9}$ Posteriormente, cursou a Aula Militar da Bahia e deu continuidade à carreira de seu pai. ${ }^{10}$ Ambos foram empreiteiros de sucesso, mas em parte significativa da documentação coeva eram designados apenas como “pedreiros”. Isso não impediu que Manoel de Oliveira Mendes iniciasse uma trajetória de

Roberto de Mello Pereira e Rosângela Santos (eds.), João da Silva Feijó: um homem de ciência no Antigo Regime português (Curitiba: Editora da UFPR, 2012), pp. 22-33.

9 Arquivo Histórico Ultramarino (AHU), Lisboa, Arquivo Administração Central (ACL), Fundo Conselho Ultramarino (CU 005), cx. 73, doc. 6.095, Requerimento de Manuel de Oliveira Mendes solicitando dispensa dos postos imediatos e provisão para preferir as bandeiras que vagarem nos terços da mesma praça da Bahia, Salvador, [ca. jun. 1742].

10 Manuel de Oliveira Mendes aparece casado com Maria do Rosário do Monte Carmo Pereira na certidão de nascimento de seu filho Luís Manuel de Oliveira Mendes, o Barão de Itapicuru de Cima. Todavia, deve ser referência a um segundo casamento, pois não parece que tenha sido a mãe de Luís Antônio e de Filipe, uma vez que não há indícios de que ela integrasse a família materna de ambos. AHU, ACL, CU 005, Série Castro e Almeida (CA), cx. 112, doc. 22.125, Requerimento de Luís de Oliveira Mendes solicitando justificação dos serviços prestados por seu pai Manuel de Oliveira Mendes, Salvador, [ca. dez. 1796]. 
ascensão social. Assim, construiu para a família um grande solar ${ }^{11}$ e chegou a solicitar à Coroa a prebenda da Ordem de Cristo, a qual era considerada um atestado de limpeza de sangue e passaporte para a elite colonial. ${ }^{12}$ Sua pretensão não foi atendida, mas a benesse foi posteriormente dada a seu filho Luís Manuel, com dispensa das habilitações, ou seja, a Coroa portuguesa fez vistas grossas a qualquer eventual impedimento que houvesse em relação a essa família de "pedreiros". ${ }^{13}$

Manuel de Oliveira Mendes também não descurou de outra estratégia de elevação social corrente na colônia: o investimento na agricultura escravista. Os historiadores João Fragoso e Manolo Florentino, ao perceberem que a elite mercantil carioca perseguiu o ideal de vir a ser aristocracia terratenente, desenvolveram a noção de "arcaísmo como projeto”. ${ }^{14}$ No caso dos Oliveira Mendes, a origem da riqueza não era exatamente de proveniência mercantil, mas da construção civil. Todavia, da mesma forma, parte do capital familiar iria desaguar em atividades nobilitantes, que talvez possam ser consideradas mais arcaicas do ponto de vista de uma racionalidade puramente econômica: de rentistas urbanos e proprietários rurais. Luís Manuel de Oliveira Mendes e Almeida, um dos filhos de Manuel, representa o braço da família que avançou decididamente em direção à agricultura escravista. Tornou-se um importante latifundiário da região de Santo Amaro, no Recôncavo Baiano. Luís Manuel deu origem a um dos ramos titulados da família. Foi agraciado, em 1825, com a honraria de Barão de Itapicuru de Cima. Um de seus filhos, Manuel de Oliveira Mendes, ascendeu a Visconde de Itapicuru de

11 O solar da família, situado no largo hoje conhecido como Praça dos Veteranos, em Salvador, ficou por herança para um de seus netos, o segundo Barão de Itapicuru de Cima.

12 AHU, ACL, CU 005, cx. 168, doc. 12.738, Requerimento do Tenente Manuel de Oliveira Mendes solicitando hábito da Ordem de Cristo, Salvador, [ca. fev. 1773].

13 Arquivo Nacional da Torre do Tombo (ANTT), Lisboa, MCO/A-C/002-010/ 0012/00050, Diligência de habilitação para a Ordem de Cristo de Luís Manuel de Oliveira Lobato Mendes, Lisboa, 3 abr. 1799.

14 João Fragoso e Manolo Florentino, O arcaísmo como projeto: mercado atlântico, sociedade agrária e elite mercantil em uma economia colonial tardia, Rio de Janeiro, c.1790-c.1840, Rio de Janeiro: Civilização Brasileira, 2001. 
Cima, outro, Luís Manuel de Oliveira Mendes, foi galardoado com o título de Barão de Traripe. ${ }^{15}$

Dessa forma, netos e bisnetos do "arquiteto" Manuel de Oliveira Mendes deram continuidade à trajetória de ascensão social da família, seja por meio dos estudos, seja pelo caminho da posse de terras e escravos. Em três gerações, os descendentes do mestre construtor Filipe de Oliveira conseguiram abandonar o exercício de atividades consideradas pouco nobres e se tornaram latifundiários, políticos e bacharéis do Império brasileiro.

A formação universitária proporcionada por Manuel de Oliveira Mendes a seus filhos Filipe e Luís Antônio de Oliveira Mendes também se insere entre as estratégias de ascensão social adotadas pela família. A parentela materna de ambos também deve ter contribuído para isso, pois nela estavam incluídos diversos letrados. O tio Pedro Paulo Dias Lobato também passara pela Universidade de Coimbra e era um advogado importante na Cidade da Bahia. Outros dois tios, os padres João Lobato e Cipriano Lobato Mendes foram jesuítas.

O patriarca desse ramo familiar era o boticário, familiar do Santo Ofício e capitão-mor da Bahia Antônio Lobato Mendes, natural de Abrantes e casado com Mariana Dias de Jesus. Seu filho Cipriano, tio de Luís Antônio, ao solicitar uma prebenda à Coroa, afirmaria que "nem o suplicante, nem seus ascendentes foram presos, nem penitenciados no Santo Ofício, nem incorreram vileza nem infâmia pública”. ${ }^{16}$ Enfim, eram gente bem posta na sociedade baiana, de origem portuguesa e cristã-velha. A existência de uma botica na trajetória econômica da família, ou seja, uma loja de porta aberta, não parece ter sido impeditivo social. Eles também sofreram a tentação agrária e tinham fazendas no Piauí.

15 Barão de Vasconcellos e Barão Smith de Vasconcellos, Archivo nobiliarchico brasileiro, Lausanne: L. A. Concorde, 1943, p. 217 e p. 513.

16 ANTT, TSO-CG-A-008-002-1118, Diligência de Habilitação de Cipriano Lobato Mendes, Lisboa, [ca. 1770]. 
Luís Antônio de Oliveira Mendes iniciou seus estudos universitários aos dezenove anos de idade, "quando a impulsos do Patriotismo, por Amor às Letras, fora arrancado dos Braços Paternos” para estudar na Universidade de Coimbra. ${ }^{17}$ Chegou àquela cidade em 1769, quando se matriculou em Instituta, a cadeira preparatória e introdutória da instrução universitária propriamente dita. ${ }^{18}$ No ano seguinte, iniciou seu aprendizado na Faculdade de Leis. O estudante baiano viveu em Coimbra exatamente no período dos preparativos e da implantação da reforma da Universidade promovida pelo Marquês de Pombal. ${ }^{19}$

Concluído o curso de direito, em 1777, mudou-se para Lisboa, onde começou a advogar. ${ }^{20}$ Durante as quatro décadas em que viveu na capital do Império, atuou como advogado na Casa de Suplicação, na Nunciatura Apostólica e na Câmara Eclesiástica. ${ }^{21}$ A ida de Oliveira Mendes para Lisboa e o início de sua vida profissional coincidem com a criação da Academia Real das Ciências de Lisboa. Até pelo tipo de formação recebida na universidade, os bacharéis eram integrantes natos da república das letras e ocuparam lugar de destaque em todas as academias portuguesas. Não é de estranhar, portanto, que Oliveira Mendes tenha se aproximado da Academia.

17 Biblioteca Nacional de Portugal (BNP), Lisboa, cód. 1.657, f. 3, Luís Antônio de Oliveira Mendes, Memória da Reforma do Foro Judicial, Salvador, 1821.

18 Também chamada de Statuta.

19 Sobre a reforma, ver Magnus Roberto de Mello Pereira e Ana Lúcia Rocha Barbalho da Cruz, "Ciência e memória: aspectos da reforma da Universidade de Coimbra de 1772”, Revista de História Regional, v. 14, (2009), pp. 7-48.

20 Arquivo da Universidade de Coimbra (AUC), Coimbra, ELU/UC-AUC/B/ 001-001/003093, Índice de alunos da Universidade de Coimbra, Coimbra, 1772-1777.

21 Biblioteca Nacional do Brasil (BNB), Rio de Janeiro, C-0500, 035 n. 001-002, Licenças concedidas a Luís Antônio de Oliveira Mendes para advogar na Casa de Suplicação de Lisboa, Lisboa, 3 maio 1787; no Auditório da Cúria Patriarcal de Lisboa, Lisboa, 15 maio 1799; e no Tribunal da Nunciatura de Lisboa, Lisboa, 22 jun. 1799. 


\section{Nisi utile est quod facimus, stulta est gloria}

Durante o reinado de Dona Maria I, na esteira da política reformista de caráter ilustrado encetada por Pombal, aprofundaram-se as reflexões sobre o desenvolvimento econômico, social e político de Portugal e suas colônias. Há muito, a historiografia abandonou a ideia dicotômica de uma "viradeira" mariana e tem observado antes continuidades em relação ao reinado de seu pai. De acordo com Jobson Arruda, “a política pombalina tem sequência mesmo depois da viradeira e apresenta um caráter integrado. Indústria, agricultura e comércio são objetos de ação governamental, definindo um lugar de ação das políticas públicas com elevado grau de unidade”. ${ }^{22} \mathrm{O}$ papel instrumental concedido às ciências também não sofreria solução de continuidade.

Sob a divisa de Fedro, "Nisi utile est quod facimus, stulta est gloria" ou "Se não for útil o que fizermos, a glória será vã”, 23 foi fundada, em 1779, a Real Academia de Ciências de Lisboa. Ainstituição nascia do esforço de um grupo de intelectuais portugueses no sentido de conjugar os conhecimentos científicos com as necessidades econômicas da nação. Fundação tardia, se comparada à de suas congêneres. Instalada “à imitação de todas as nações cultas”, a Academia era instituída para promover “o aumento da Agricultura, das Artes e da Indústria Popular [... ] procurando introduzir o amor à ocupação e a toda espécie de trabalho, que possa redundar em benefício da Pátria”. ${ }^{24}$ Segundo o historiador José Luís Cardoso, a "Academia procurava romper as distâncias entre o discurso teórico de feição abstrata e as ações práticas baseadas na tradição. E assim

22 José Jobson de Andrade Arruda, "Decadência ou crise do império luso-brasileiro: o novo padrão de colonização do século XVIII”, Revista USP, n. 46 (2000), p. 69.

23 Fedro, Fabulce 3.17.12.

24 Academia Real das Ciências de Lisboa, Plano de Estatutos em que convieram os primeiros sócios da Real Academia das Sciencias, com beneplácito de Sua Majestade, Lisboa: Régia Oficina Tipográfica, 1780, p. 3 e p. 8. 
se fazia mensageira dessa vontade, tão característica do espírito das Luzes, de ousar saber e usar saberes". ${ }^{25}$

O findar do século XVIII iria encontrar Oliveira Mendes como assíduo participante deste ambiente de sociabilidades. Entre os luso-brasileiros coimbrões, apenas José Bonifácio de Andrada e Silva, de quem tornara-se parceiro, foi mais atuante nessa agremiação de letrados. ${ }^{26}$ Todavia, há um descompasso entre as trajetórias de ambos. Andrada tornou-se sócio correspondente em 1789, antes mesmo de voltar para Lisboa após uma década de estágios de formação científica pela França e pelo norte da Europa com patrocínio da Coroa portuguesa. Em 1809, foi alçado a sócio efetivo e em 1816 passou a ocupar o cargo de Secretário-geral da instituição. Já Oliveira Mendes nunca passou de sócio correspondente, nomeado em 1805, ano em que houve uma grande abertura para a inclusão de luso-brasileiros nessa categoria. A diferença entre ambos é que José Bonifácio, além de transitar no círculo de D. Rodrigo de Souza Coutinho, era mineralogista de algum renome, um homem de ciências tout court, enquanto Oliveira Mendes era apenas um aficcionado, um advogado diletante, para quem a ciência foi uma distração custeada com recursos próprios:

Como bom Patriota, apenas valendo-me das distrações do quanto me ocupa no necessário e pesado tráfico da minha subsistência, sem que nada deva ao Público, tudo porém aos meus esforços, sempre me propus, do modo possível, entre escassas fadigas, ser útil à Nação e agradecido à Pátria. ${ }^{27}$

25 José Luís Cardoso, “Introdução” in José Luís Cardoso (ed.), Memórias Económicas da Academia Real das Ciências de Lisboa, 1789-1815 (Lisboa: Banco de Portugal, 1990), v. 1, p. 18.

26 Sobre a participação de brasileiros na Academia, ver Péricles Pedrosa Lima, "Homens de ciência a serviço da Coroa: os intelectuais do Brasil na Academia Real das Ciências de Lisboa - 1799/1822”, Dissertação (Mestrado em História), Universidade de Lisboa, Lisboa, 2009.

27 Academia das Ciências de Lisboa (ACL), Série Azul, cód. 377, f. 113, Memória sobre a economia da materia combustível, Lisboa, 27 abr 1811. 
Amadores das ciências tornaram-se comuns desde o Renascimento, dando forma a uma figura tipo que foi reconhecidamente essencial à constituição das diversas disciplinas científicas modernas. ${ }^{28} \mathrm{Na}$ historiografia portuguesa e brasileira sobre a época, o estudo da atuação dos cientistas amadores ainda está por ser feito, mas não porque não tenham existido. Entre os egressos da Universidade de Coimbra contam-se dezenas de pessoas que, como Luís Antônio de Oliveira Mendes, buscaram elevação e reconhecimento pessoal tornando-se amateurs das ciências.

Inicialmente, os interesses do advogado centravam-se no desenvolvimento de mecanismos voltados à melhoria da vida produtiva, como aperfeiçoar moinhos, arados, carros de transporte, iluminação pública etc. Diríamos que pretendia ser um inventor. O rol de suas pretensões acadêmicas foi incluído em um pequeno livro no qual apresentava a proposta de construção de uma escada pantográfica para combater incêndios (Figura 1).

Apesar de ter feito algumas poucas incursões nos inventos pretendidos, os interesses científicos de Luís Antônio de Oliveira Mendes acabariam mudando e passaram a ser pautados, na prática, pelos da Academia Real das Ciências de Lisboa. Dentre as diversas atividades estatutárias dos acadêmicos, os membros efetivos, inclusive os correspondentes, deveriam apresentar, pelo menos uma vez por ano, um texto original. Oliveira Mendes foi um dos raros sócios da Academia que comprovadamente enviaram memórias com regularidade. É plausível supor que foi sua constante atuação acadêmica que motivou a instituição a agraciá-lo, quando retornou ao Brasil, com a edição de uma listagem de seus textos impressos e manuscritos. ${ }^{29}$ Por meio de tal arrolamento é possível observar que parte substancial de sua obra era de cunho científico-tecnológico, que a economia agrícola e o continente africano ocuparam

28 Jean-Marc Douin, "Les amateurs d'histoire naturelle: promenades, collectes et controverses”, Alliage, n. 69 (2011), pp. 35-47; Krzysztof Pomian, Collectionneurs, amateurs et curieux: Paris-Venise, XVIe-XVIIIe siécles, Paris: Gallimard, 1987.

29 BNB, C-0500, 035 n. 001-002, Catálogo das obras impressas e manuscritas de Luís Antônio de Oliveira Mendes. Lisboa, [ca. 1811]. 
espaço importante em sua atenção, que ele fez incursões no beletrismo e que também se dedicou com alguma frequência a estudos de caráter moral e religioso. Esta última parte de sua obra perdeu-se quase toda. Já os segmentos dedicados à ciência e à economia agrária foram notavelmente bem preservados e ainda hoje estão disponíveis em diversos arquivos e bibliotecas.

Figura 1

Carro de combate a incêndios inventado por Oliveira Mendes (1792)

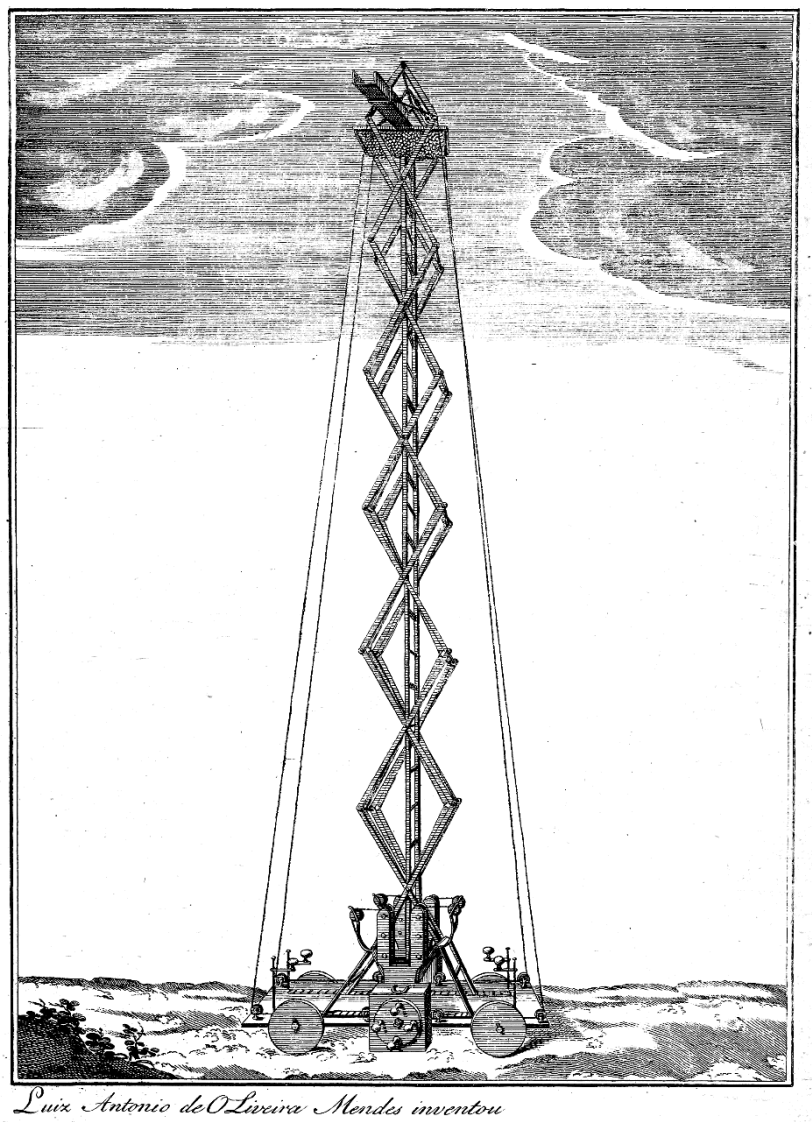

Fonte: Luiz Antonio de Oliveira Mendes, Memoria analitico-demonstrativa da maquina de dilatação, e de contracção. Lisboa: Joaquim Jozé Florencio Gonçalves, 1792, pp. 23-27. 
A partir de 1789, a Academia passou a editar a publicação periódica Memórias económicas para o adiantamento da agricultura, das artes, e da indústria em Portugal, destinada a difundir os estudos enviados pelos associados. Acompanhando o modelo de suas congêneres europeias, a instituição assumiu o papel de indutora de estudos sobre matérias consideradas importantes para a economia de Portugal e dos territórios ultramarinos. ${ }^{30}$ Periodicamente propunha "programas" e submetia as contribuições recebidas a uma comissão julgadora. ${ }^{31} \mathrm{~A}$ monografia vencedora de cada programa seria, em princípio, premiada com sua publicação nos periódicos da instituição. $\mathrm{O}$ bacharel baiano foi um participante assíduo desses certames acadêmicos. Em 1792, a Academia de Ciências de Lisboa propôs um programa que dizia respeito diretamente às colônias americanas e africanas:

Determinar com todos os seus sintomas as doenças agudas e crônicas que mais frequentemente acometem os Pretos recém-tirados da África: examinando as causas da sua mortandade depois da sua chagada ao Brasil: se talvez a mudança do clima, se a vida mais laboriosa, ou se alguns outros motivos concorrem para tanto estrago: e finalmente indicar os métodos mais apropriados para evitá-lo, prevenindo-o; e curando-o. Tudo isto deduzido da experiencia mais sisuda e fiel. ${ }^{32}$

Oliveira Mendes foi o autor contemplado e apresentou sua monografia em sessão pública realizada em 12 de maio de 1793. Todavia,

30 Ver Jeremy L. Caradonna, "Prendre part au siècle des Lumières: Le concours académique et la culture intellectuelle au XVIIIe siècle”, Annales. Histoire, Sciences Sociales, v. 64, n. 3 (2009), pp. 633-662.

31 José Alberto Teixeira Rebelo da Silva, "A Academia Real das Ciências de Lisboa (1779-1834): ciências e hibridismo numa periferia europeia”, Tese (Doutorado em História), Universidade de Lisboa, Lisboa, 2015, pp. 296-297.

32 Luís Antônio de Oliveira Mendes, "Determinar com todos os seus sintomas as doenças agudas e crônicas que mais frequentemente acometem os Pretos recém-tirados da África” in Academia Real das Ciências de Lisboa (org.), Memorias Economicas da Academia Real das Sciencias de Lisboa (Lisboa: Academia Real das Ciências de Lisboa, 1812), v. 4, p. 1. 
a edição das Memórias economicas estava suspensa à época. A publicação só veio a ocorrer em 1812, quando o periódico foi retomado, já na conjuntura que sucedeu à expulsão dos franceses de Portugal. ${ }^{33}$ No ano seguinte, a memória foi editada n’O investigador portuguez, periódico publicado na Inglaterra. ${ }^{34}$ Este é um dos únicos textos de Luís Antônio de Oliveira Mendes que sobreviveu ao tempo. A memória intitulada "Determinar com todos os seus sintomas as doenças agudas e crônicas que mais frequentemente acometem os Pretos recém-tirados da África” vem chamando a atenção dos estudiosos da escravidão desde o século XIX. Ainda hoje, referências a ela são constantes tanto na historiografia brasileira quanto na estrangeira. Não fosse por essa obra, hoje o autor estaria esquecido.

\section{O aumento da agricultura}

O programa da Academia sobre as enfermidades dos cativos não tinha o propósito de tratar da escravidão em si, mas fazia parte de conjunto referente à melhoria da economia agrária no universo português. Esta era uma das áreas de conhecimento que se situava na centralidade dos propósitos da instituição. Com Pombal, e mais ainda com D. Rodrigo de Sousa Coutinho, a produção e difusão de conhecimentos sobre técnicas agrícolas modernas assumiu lugar central nas políticas econômicas da Coroa. A criação da Casa Impressora do Arco do Cego, mantida sob a chefia do naturalista luso-brasileiro Mariano da Conceição Veloso,

33 Luís Antônio de Oliveira Mendes, "Determinar com todos os seus sintomas as doenças agudas e crônicas que mais frequentemente acometem os Pretos recém-tirados da África” in Academia Real das Ciências de Lisboa (org.), Memorias Economicas da Academia Real das Sciencias de Lisboa (Lisboa: Academia Real das Ciências de Lisboa, 1812), v. 4, pp. 1-82.

34 Luís Antônio de Oliveira Mendes, "Memoria a respeito dos escravos e commercio da escravatura \&c.”, O investigador portuguez em Inglaterra, v. 8 (1813), pp. 1-18; Luís Antônio de Oliveira Mendes, "Memoria a respeito dos escravos e commercio da escravatura \&c.”, O investigador portuguez em Inglaterra, v. 9, (1814), pp. 12-34. 
é o mais candente signo da importância atribuída à política agrícola. Nas publicações da Imprensa Régia e da Academia das Ciências a questão não ficava atrás. Assim, não é de estranhar que Oliveira Mendes visitasse com frequência temas dessa natureza.

No conjunto da vasta obra que dedicou ao assunto transparece que o autor compartilhava com o meio acadêmico luso ideias correntes sobre o estado da produção agrícola em Portugal e suas colônias. No entanto, não se dedicou a fazer apenas a crítica da situação da agricultura, nem a discorrer sobre sua decadência em Portugal, como era comum na produção memorialista da época. ${ }^{35}$ Mendes foi antes um autor propositivo, que partia do princípio fisiocrata de que a riqueza provinha da terra e que concebia a ciência e a tecnologia (a indústria, consoante dizia), como promotoras do desenvolvimento agrícola.

Sendo o homem um indivíduo que por necessidade da sua mesma existência se deve alimentar do que e do quanto a terra posa comodamente produzir; por isso mesmo os cuidados de uns, em que é mais pronta e mais eficaz a oficiosidade para com os outros seus semelhantes, se devem desvelar em procurar os meios, os arbítrios e os inventos pelos quais a terra por mediação da indústria e destes esforços se facilite a entrar e a prosseguir na sua mesma intrínseca força produtiva. ${ }^{36}$

Um aspecto que particularizava as concepções do bacharel era a crítica aberta que fazia à estrutura fundiária de Portugal e suas colônias, questão que irá atravessar toda sua produção acadêmica. Nesse sentido, ele integrava o grupo de autores que à época reprovavam essa estrutura e, a partir da Academia, elaboravam propostas de sua melhoria,

35 Sobre a ideia da decadência econômica, ver José Luís Cardoso, O pensamento econômico em Portugal nos finais do século XVIII, 1780-1808, Lisboa: Estampa, 1989.

36 BNP, cód. 6.400, f. 3, Luís Antônio de Oliveira Mendes, Sinópses, anotações e arbítrios sobre o aumento da agricultura de Portugal, Lisboa, s. d. 
principalmente no Alentejo. Vale mencionar Domingos Vandelli, um dos mestres de Oliveira Mendes, e José Acúrsio das Neves. ${ }^{37}$

Via de regra, os brasileiros que passaram por Coimbra tendiam ao conservadorismo quanto a questões dessa natureza, até porque eram filhos ilustrados da elite colonial latifundiária e escravista. Na contramão dessa tendência, Luís Antônio de Oliveira Mendes propunha para Portugal um processo de redistribuição fundiária semelhante ao que hoje chamamos de “reforma agrária”. As terras incultas deveriam ser entregues a quem se dispusesse a cultivá-las. "Um terreno ou espaço desta natureza de todo perdido e entregue no ócio a um inteiro abandono parece que na sua desgraça, merecendo as primeiras atenções, deveria ser dado, sem ônus de foro ou de pensão, com toda facilidade e franqueza, a toda aquela pessoa industriosa, que se propusesse a querer beneficiar". ${ }^{38}$

Do ponto de vista legal, argumentava que nesse caso não eram defensáveis os "mal intendidos princípios, a estreiteza, e a sutileza do Direito, de que ninguém deve ser privado, e desapossado do que é seu”. Os terrenos deveriam ser tirados daqueles que se contentavam "com a vã, e prejudicial glória de os possuir na inação” e entregues a quem os amanhasse. Segundo Oliveira Mendes “não há e nem poderá jamais haver um legítimo e justo possuidor do que aquele, que tirando o terreno da inércia e do abandono, o tem beneficiado”. Considerava que a utilidade pública ultrapassava o direito à propriedade privada e que os terrenos "sendo assim conservados e detidos na inércia e na inutilidade nem aproveitam aos Senhorios nem ao público nem à sociedade”. Em decorrência, essas

37 Domingos Vandelli, "Memória sobre a agricultura deste reino, e das suas conquistas" in José Luís Cardoso (ed.), Memórias Económicas da Academia Real das Ciências de Lisboa (Lisboa: Banco de Portugal, 1990), v. 1, pp. 127-134; Domingos Vandelli, "Memória sobre a preferência que em Portugal se deve dar á Agricultura sobre as Fábricas” in José Luís Cardoso (ed.), Memórias Económicas da Academia Real das Ciências de Lisboa (Lisboa: Banco de Portugal, 1990), v. 1, pp. 185-193; José Acúrsio das Neves, "Memória sobre a Agricultura" in Manuel Villaverde de Cabral (ed.), Materiais para a História da Questão Agrária em Portugal, sécs. XIX e XX, Porto: Inova, 1974, pp. 112-127.

38 Sinópses, f. 28. 
terras deveriam ser entregues a quem as quiser cultivar, isentas “de foros, de medidas, de pensões e de laudêmios, ficando só a justa sisa por ser Rendas do Estado". ${ }^{39}$ Esta seria uma das principais medidas para estimular o desenvolvimento da agricultura em Portugal.

A inércia provocada pela ignorância e pelas práticas costumeiras era outro dos fatores aos quais Oliveira Mendes atribuía o atraso da agricultura no universo português. Para quebrar esse quadro, propunha a criação de um corpo de inspetores encarregados de difundir conhecimentos que levassem ao aumento da produtividade agrícola. Haveria um “Inspetor Geral da Agricultura Nacional” que chefiaria um quadro de Inspetores Provincianos ou Juízes Conservadores Inspetores da Agricultura Provinciana espalhados pelo Império. ${ }^{40}$ Contudo, para que a experiência tivesse sucesso, a nova magistratura deveria ser entregue a "bacharéis formados na faculdade da Filosofia, em quem residissem de profissão os vastos conhecimentos da História Natural, ou em outros quaisquer homens destas Luzes”. ${ }^{41}$ Em suma, ele tinha em mente a intelectualidade coimbrã, da qual era integrante. De forma alguma os inspetores poderiam ser comerciantes e fazendeiros, pois esses, além de desconhecerem as modernas técnicas, eram parciais e tenderiam a perpetuar o status quo.

A proposta pode até parecer mais um plano utópico de cunho iluminista, entre tantos outros concebidos à época. Todavia, nas colônias houve a implementação de um projeto muito semelhante, o qual pode ter inspirado Oliveira Mendes. Trata-se da Intendência Geral da Agricultura, estabelecida em Goa, em $1776 .{ }^{42}$ A Intendência fazia parte das reformas pombalinas e visava desenvolver a agricultura da Índia portuguesa. Entre

39 Sinópses, ff. 28-28v.

40 Sinópses, ff. 47-58.

41 BNB, 09, 02, 019, Luís Antônio de Oliveira Mendes, Discurso preliminar, histórico, introdutivo, com natureza de descrição econômica da Comarca e Cidade da Bahia, Lisboa, s. d., p. 67.

42 Edgar F. C. B. Pereira, "Pombalismo, jesuítas e a terra nas Velhas Conquistas: confisco e redistribuição de propriedade fundiária na Goa setecentista”, Dissertação (Mestrado em História), Universidade Nova de Lisboa, Lisboa, 2013, pp. 41-42. 
os seus principais intuitos estava o de pôr em prática uma política de ocupação dos baldios, tal como na proposta de Oliveira Mendes.

Outro detalhe a reter é que em 1783, época em que o advogado era atuante na Academia e escreveu a maior parte de suas monografias temáticas, foram criados os cargos de Juízes Conservadores dos Pinhais de Leiria e da Matas de Ilhéus. ${ }^{43} \mathrm{O}$ segundo ofício foi criado sob medida para Baltazar da Silva Lisboa, que já tinha proposto, em seu Discurso historico, que a Coroa passasse a empregar magistrados filósofos. ${ }^{44}$ Não é descabido supor que em sua proposta Silva Lisboa advogasse em causa própria, da mesma forma que Oliveira Mendes ao sugerir a criação de um corpo de inspetores agrícolas cujo âmbito de atuação seria a totalidade do universo luso.

Apesar da proximidade entre as inspetorias propostas por Mendes e a Intendência goesa, vale frisar que sua aproximação com o tema da agricultura nos domínios portugueses seria bastante lenta. Uma das preocupações que sempre estiveram em seu horizonte foi a ampliação da pauta de produtos exportáveis pelas colônias americanas, o que motivou seus estudos sobre o uso do pau-brasil para corantes e mastros de navios. ${ }^{45}$ Essas memórias, assim como outras apresentadas à Academia Real das Ciências, faziam parte de uma série que ele intitulou "Descobrimentos úteis do Brasil”. Todavia, a motivação desses estudos era mais voltada ao extrativismo do que propriamente à agricultura.

No ensaio sobre a economia da Bahia, acompanhando as propostas que estavam sendo difundidas por D. Rodrigo de Sousa Coutinho, Mendes traçou um primeiro esboço no qual defendia a ampliação do rol de produtos

43 Balthazar da Silva Lisboa, Annaes do Rio de Janeiro, v. 4, Rio de Janeiro: SeignotPlancher, 1835, p. 177ss.

44 Balthazar da Silva Lisboa, Discurso historico, politico, e economico dos progressos, e estado actual da Filozofia Natural Portugueza, Lisboa: Antonio Gomes, 1786.

45 ACL, Série Azul, cód. 375, f. 216-217, Luís Antônio de Oliveira Mendes, Ensaio de tinturaria com o pau-brasil, Lisboa, s.d.; ACL, Série Azul, cód. 375, f. 218-227, Luís Antônio de Oliveira Mendes, Memória sobre o modo de se conhecer quando os paus-brasil, que hão de servir para a mastreação das naus e dos navios se acham perfeitos no seo interio, para serem cortados, Lisboa, 1806. 
da agricultura colonial. ${ }^{46}$ Lembrava que deveria ser retomado o plantio de produtos que haviam conhecido sucesso efêmero, como cacau, baunilha, café e arroz, mas não só. As terras mais ao sul do Brasil eram o lugar para o cultivo de produtos de origem europeia, com o linho e os grãos para panificação, porque

Assim como somos capazes, sem haver coisa que nos desanime, de fazer sacudir o jugo pelo meio da plantação e da cultura do arroz em as nossas colônias e províncias ultramarinas, que o mesmo e que outro tanto poderemos conseguir com igual feliz sucesso em as plantações do trigo e do centeio, do que para desafio já temos tido amostras e por diversas pessoas, sem que se fale na do milho, porque esta sempre foi constante, frequente, usual e uma plantação primitiva com abundância em todas e cada uma das nossas colonias ultramarinas. ${ }^{47}$

Oliveira Mendes não apenas defendeu a cultura de gêneros europeus nas colônias como chegou a inverter raciocínios correntes. Acreditava que produtos coloniais, como a cana-de-açúcar, por exemplo, podiam ser produzidos em Portugal. Concebeu, também, o projeto de levar do Brasil mudas de árvores do mangue e plantá-las nas rias portuguesas como forma de contenção costeira e melhoria do solo. ${ }^{48}$ Anos depois ele parece ter aprofundado suas propostas, após retornar ao Brasil e se radicar na Bahia. Em 1817, em correspondência enviada ao Conde da Barca, menciona que acabara de compor uma memória sobre o tema, intitulada Princípios práticos analíticos da agricultura do continente do Brasil..$^{49}$ Segundo o autor, a obra era composta de 21 capítulos e se achava entregue

46 Sinópses, ff. 47-52.

47 Sinópses, f. 47v.

48 Sinópses, ff. 30-34v.

49 Arquivo Distrital de Braga (ADB), Braga, FAM/FAA-AAA/000889, Cota atual B-11 $(18,3)$, Carta ao Conde da Barca felicitando-o pelo restabelecimento de sua saúde e solicitando proteção para ser indicado para uma magistratura na Bahia, Salvador, 2 mar. 1817. 
a um copiador. Mendes aproveitou a oportunidade para pedir a proteção do conde para uma futura publicação, uma vez que não tinha recursos para isso, pois se achava onerado com encargos familiares. A memória não chegou a ser publicada e o paradeiro do manuscrito, se sobreviveu, é desconhecido.

\section{A lastimosa situação dos pretos escravos}

O estudo da África e da escravidão não aparece na agenda inicial dos propósitos acadêmicos de Oliveira Mendes. Todavia, ele relata que, desde criança, interessou-se pelo continente. "Nos primeiros anos da infância, por ter sido senhor de muitos escravos daquela Costa, deles mesmos mendiguei os primeiros informes a este respeito”. ${ }^{50}$ Além do que, Mendes afirmaria anos depois que os costumes de sua terra natal eram muito "mais Africanos do que Europeus”. ${ }^{51}$ Assim, conhecer o Brasil, ou mais especificamente a Bahia, era também conhecer a África. Não é de estranhar, portanto, que a África lhe despertasse particular interesse acadêmico, em especial a questão da escravidão, sobre a qual escreveu a já mencionada memória sobre as enfermidades dos escravos, premiada pela Academia das Ciências, mas não apenas. Ele também abordou o continente nos seguintes textos: "Memória sobre os costumes dos povos africanos”, "Dicionário da língua africana, com restrição ao reino Daomé” e "Descrição da capitania de Moçambique, suas povoações e produções”. Dos três, apenas o primeiro sobreviveu e foi publicado na revista Afro-Ásia, acompanhado de comentários do historiador Alberto da Costa e Silva.

50 Luís Antônio de Oliveira Mendes, "Memória histórica sobre os costumes particulares dos Povos Africanos, com relação privativa ao Reino de Guiné, e nele com respeito ao Rei de Daomé” in Alberto da Costa e Silva, “A memória histórica sobre os costumes particulares dos povos africanos, com relação privativa ao Reino da Guiné, e nele com respeito ao rei de Daomé, de Luís Antônio de Oliveira Mendes”, Afro-Ásia, v. 28 (2002), p. 281.

51 Memória da Reforma, 1821, f. 36. 
Diversos autores que estudaram os textos de Oliveira Mendes, em especial a memória que trata da melhoria das condições do tráfico, consideraram-no um escravista disfarçado: a humanização do transporte de cativos seria um paliativo que dava argumentos para a continuidade da escravização dos africanos. Tendo em vista os diversos indícios presentes na obra do bacharel, não é isto o que se observa. Embora ele não tenha sido nada parecido com um abolicionista radical, foi um crítico constante do próprio instituto da escravidão.

Como era norma geral na época, os textos de Oliveira Mendes sobre o continente negro tinham o preconceito como sua principal marca: a África era a terra da barbárie, a única parte do velho mundo que “desde a sua origem até hoje, medindo séculos da sua existência, sem melhoração alguma, se tem conservado na sua mesma incultura e impolidez". ${ }^{52}$ Todavia, Oliveira Mendes não se limitou a esse tipo de prejulgamento e fez algumas tentativas de avançar na compreensão da África, das causas da escravidão e do impacto que ela tinha sobre o continente.

O escravismo do período moderno teve entre suas justificativas uma série de teorias raciais que hierarquizavam os grupos humanos com base na aparência (fenótipo). Essas noções eram tão arraigadas entre os europeus, beneficiários dessa hierarquia, que ainda no século XVIII as ciências naturais tiveram dificuldade de abrir mão de tais princípios. Na zoologia, a produção de "híbridos férteis” era um dos critérios utilizados para determinar se dois animais de características próximas pertenciam a uma mesma espécie, ou não. Lineu foi um dos responsáveis pela formulação de tais princípios. Todavia, mesmo diante da evidência da capacidade geral de hibridização entre as variedades geográficas humanas, ele dividiu os homens em quatro espécies, negando os princípios utilizados para classificar os demais animais. Mais tarde, seus seguidores ampliaram a caracterização das variedades humanas, ultrapassando o campo físico para hierarquizar as espécies a partir das qualidades morais a elas atribuídas.

52 Mendes, “Memória histórica”, p. 257. 
Os humanos dividir-se-iam em: Homo americanus - vermelhos, obstinados, regendo-se por costumes; Homo europaeus - branco, inteligente, regendo-se por leis; Homo africanus - preto, manhoso, regendo-se por caprichos; e Homo asiaticus - amarelo, rude, regendo-se por opiniões. ${ }^{53}$ Oliveira Mendes negava teorias deste tipo, colocando-as no campo da irreflexão e do preconceito.

Não sei bem se tamanhos descuidos se davam às irreflexões dos iluminados, se aos desconhecimentos, se às maldições do infeliz Chaim, se à insensibilidade, se à falta de aplicação dos meios, se à positiva e entranhada aversão que injustamente lhe temos sem nos haver ofendido, debaixo de uns prejuízos comuns e inveterados de que esses rudes povos, nossos semelhantes, no total afaste com erro manifesto, se considerem, com injúria dos humanos sentimentos, ser de outra espécie e natureza, quando não são? ${ }^{54}$

Mendes não era exatamente uma exceção, até porque tais noções de hierarquia racial estavam sendo questionadas por diversos pensadores europeus no período. ${ }^{55}$ Mesmo entre filhos ilustrados da elite luso-brasileira, oriundos de famílias diretamente interessadas e dependentes da manutenção do escravismo, havia aqueles que negavam abertamente a hierarquização racial, principalmente os que ocuparam postos administrativos na África. O bacharel Rafael José de Souza Correa Melo, enviado a Angola como ouvidor e juiz de fora da Capitania de Benguela, era

53 Caroli Linné, Systema naturae per regna tria naturae: secundum classes, ordines, genera, species, cum characteribus, differentiis, synonymis, locis, Lugduni: G. E. Beer, 1789, pp. 21-23.

54 Mendes, "Memória histórica”, p. 257. Chain ou Chan, como era grafado anteriormente, é Cam, um dos filhos de Noé, aquele que teria dado origem à "raça negra”. Cam teria visto Noé embriagado e nu e, em vez de cobri-lo, foi contar aos irmãos. Por conta desse episódio Noé amaldiçoou-o: “Maldito seja Cam; servo dos servos seja dos seus irmãos” (Gênesis 9, 25). Essa passagem bíblica serviu de justificativa teológica para a escravização dos povos negros.

55 Ver Thomas Bender (ed.), The Antislavery Debate: Capitalism and Abolitionism as a Problem in Historical Interpretations, Berkeley: University of California Press, 1992. 
explícito sobre a questão. Ele se demonstrava conhecedor das teorias raciais europeias que atribuíam as diferentes colorações de pele a variações climáticas, todavia não reconhecia que tais variações implicassem em inferioridade. "Os Negros tem reconhecido que a obra simples da modificação dos raios da luz sobre a cor diferente da sua pele não constitui com efeito inferioridade alguma, nem de músculos nem de ânimo”. ${ }^{56}$

Se a escravidão não era um fato decorrente da hierarquia racial determinada pela natureza, era condenável pela razão e por outros pressupostos de fundo religioso, ético e moral. Desde o final do século XVIII, uma parte significativa da intelectualidade nascida nas colônias americanas já nutria expectativas antiescravistas, todavia de forma condicionada e limitada. A escravidão era um mal, mas um mal necessário. O Brasil “ainda” necessitava do braço escravo e a abolição do tráfico e a libertação dos cativos seriam consequências do próprio desenvolvimento econômico das colônias. Por exemplo, o militar luso-brasileiro Elias Alexandre da Silva Correia, que viveu em Angola, achava que a escravidão era um malefício ainda indispensável, porém finito. Antecipava o dia em que as minas de ouro tivessem secado, as baleias acabado e as terras vissem diminuir a fertilidade e que a Coroa abolisse a escravidão, como já fizera em Portugal. Finalmente, no Brasil iria "começar um estabelecimento mais sólido, servindo por indivíduos jornaleiros ao uso da Europa”. Contudo, afirmava que a "pouca população do Brasil não pode ainda prestar meios a esta solidez". ${ }^{57}$

Isso não impedia que entre os letrados da época fosse frequente a percepção de que a escravização dos africanos era feita ao arrepio das leis europeias e que as práticas legais africanas tinham sido abastardadas

56 AHU, Angola, cx. 71, doc. 60, Rafael José de Souza Correa Melo, Memória, Benguela, 1786.

57 Ver Magnus Roberto de Mello Pereira, “Quem necessita pede: as mercês régias e a carreira imperial de um militar letrado luso-brasileiro do século XVIII” in Magnus Roberto de Mello Pereira e Ana Lúcia Rocha Barbalho da Cruz, Elias Alexandre da Silva Correia: um militar brasileiro em Angola (Curitiba: Editora da UFPR, 2014), p. 69. 
para atender às conveniências do tráfico. ${ }^{58}$ Nos dois lados do continente africano, tais práticas foram observadas e criticadas por luso-brasileiros a serviço da Coroa. As frequentes secas em Moçambique tinham efeitos devastadores, levando muitos, ou por impossibilidade de pagar tributos, ou para escapar à morte pela fome, a “venderem” os seus corpos. No entanto, este ato, que era interpretado oportunisticamente pelos europeus como opção voluntária pelo cativeiro, tinha um sentido completamente diverso para os africanos. "Porque dizem vêm vender o corpo é para servirem como qualquer moço europeu que assenta sua soldada, com seu amo, e nem por isso ficam seus cativos”, explicava Antônio Pinto de Miranda. ${ }^{59}$ Em Angola não era diferente, conforme Silva Correia, as instituições legais nativas passaram a ser utilizadas para produzir escravos: "sendo a venda de cativos o objeto que produz mais conveniência, é o cativeiro a pena dos mais insignificantes delitos: delitos que não incluindo ação alguma criminável são arbitrados pela fantasia dos seus bárbaros legisladores” ${ }^{60}$

Oliveira Mendes fazia eco a condenações dessa natureza. Denunciava, à partida, os falsos argumentos de que as nações escravistas europeias autorizavam o tráfico com o objetivo de "resgatar" os africanos. Como sabemos, a palavra fora distorcidamente utilizada querendo significar que os europeus os resgatavam da barbárie, das falsas crenças ou da própria escravidão. Ele percebe que são os europeus que "favorecem e prosperam a guerra e a hostilidade intestina” na África com vistas à obtenção de escravos. ${ }^{61}$

58 Sobre a questão, ver o clássico do jornalista e historiador Basil Davidson, Mãe Negra: África - os anos de provação, Lisboa: Livraria Sá da Costa Editora, 1961.

59 António Pinto de Miranda, “Memória sobre a costa da África. (circa 1766)” in António Alberto de Andrade (ed.), Relações de Moçambique setecentista (Lisboa: Agência Geral do Ultramar, 1955), p. 268.

60 Elias Alexandre da Silva Correia, "História de Angola” in Pereira e Cruz, Elias Alexandre da Silva Correia, p. 338. O naturalista Joaquim José da Silva foi outro brasileiro a tratar das práticas jurídicas da região de Angola. Joaquim José da Silva, "Extrato da viagem que fez ao sertão de Benguella”, O Patriota, n. 3 (1813), pp. 49-60.

61 Mendes, “Memória histórica”, p. 259. 
Tal como os demais homens, os habitantes da África negra poderiam ser redimidos pelo conhecimento: o "pensar filosófico".

Seja qualquer que for o princípio desconhecido, ou ainda todos sobreditos apostados contra eles, para que os faça tanto mais infelizes, como temos a certeza, derivada do histórico em comum e, em particular, confirmada pela evidência, a que se não resiste, de que vivem em um manifesto e comprovado atrasamento, submergidos em tudo que seja infelicidade e infortúnios, degradados até das primeiras ideias, que possam ser concernentes aos fins da sua desejada prosperidade, tanto basta e superabunda, para no estado da compaixão entrar nos estímulos de os socorrer um pensar filosófico. ${ }^{62}$

A escrita de Oliveira Mendes não facilita em nada a compreensão de suas ideias, mas é possível dizer que nesse segmento, mais do que manifestar crenças bíblicas, ele fala de preconceitos, inclusive o de negar aos negros a condição humana. Já em relação aos traficantes e aos fazendeiros coloniais que se beneficiavam do tráfico humano, Oliveira Mendes era implacável. Os termos usados para qualificá-los são barbárie, crueldade e tirania.

Na terceira parte tratarei do horroroso artigo e da lastimosa situação dos pretos escravos [...] quando na América os tiranos e cruéis senhores os comprão e os ficam possuindo até o último espaço das suas vidas.

As diversas crueldades experimentadas pelos pretos escravos em todas estas referidas idades fazem gelar o sangue nas veias do fiel e experimentado escritor. ${ }^{63}$

Uma peculiaridade muito importante a reter de seu Discurso acadêmico sobre as doenças dos escravos é a existência de duas versões do

62 Mendes, “Memória histórica”, p. 258.

63 Mendes, “Discurso acadêmico ao programa”, p. 2. 
texto. ${ }^{64}$ Pode-se supor que as acusações de brutalidade contidas no ensaio tenham levado à censura da primeira edição. $\mathrm{O}$ paradeiro do manuscrito original é desconhecido e, portanto, não existem indícios documentais de como isto teria ocorrido. A Academia Real das Ciências de fato publicou duas versões do volume das Memórias econômicas em que aparece o texto premiado de Oliveira Mendes. ${ }^{65} \mathrm{Na}$ edição modificada, a monografia foi depurada dos termos mais contundentes usados para se referir aos traficantes e à elite escravista brasileira. ${ }^{66}$ Uma vez que as publicações da Academia eram editadas sob a chancela da Coroa, elas estavam dispensadas de passar pela apreciação da Real Mesa Censória. A censura era feita internamente. É cabível supor que após a publicação tenha havido algum processo de pressão, ou mesmo uma ordem superior, que tenha levado a direção da Academia a recolher a primeira edição e substituí-la por outra em que o texto do advogado foi expurgado. Isso é uma suposição, pois não há certezas quanto à ordem da publicação das versões. A psiquiatra Ana Maria Oda presume que a variante depurada das críticas mais pesadas aos traficantes e senhores de escravos tenha sido publicada primeiro. ${ }^{67}$ Todavia, a publicação da memória n’O investigador portuguez, no ano seguinte, corrobora a primeira hipótese, uma vez que ela reproduz o texto menos crítico e, portanto, parece ter sido essa a variante que circulou à época e tornou-se mais conhecida pelo público.

A existência das duas versões distintas fez com que as ideias de Oliveira Mendes sobre a escravidão fossem apreendidas de forma

64 Para a confrontação das duas versões, ver Sérgio Luiz Godoy e Lupércio Antônio Pereira, “A questão do tráfico de escravos no pensamento de Luís Antônio de Oliveira Mendes”, V Congresso Internacional de História, Maringá, 2011 ש.

65 Até onde foi possível alcançar, o primeiro historiador a dar notícia de que havia duas versões do texto foi Robert Slenes. Ver Robert W. Slenes, “African Abrahams, Lucretias and Men of Sorrows: Allegory and Allusion in the Brazilian Anti-slavery Lithographs (1827-1835) of Johann Moritz Rugendas”, Slavery and Abolition, v. 23, n. 2 (2002), pp. 147-168.

66 Ana Maria Oda, "O banzo e outros males: o páthos dos negros escravos na Memória de Oliveira Mendes”, Revista Latinoamericana de Psicopatologia Fundamental, v. 10, n. 2 (2007), p. 353.

67 Oda, “O banzo e outros males”. 
contraditória pela historiografia. No Brasil, Penalves Rocha, o principal estudioso do tema, sequer menciona o Discurso acadêmico sobre as causas das enfermidades dos cativos entre os textos antiescravistas elaborados por luso-brasileiros sob o influxo do Iluminismo. ${ }^{68} \mathrm{O}$ historiador português José Capela foi mais longe: “o que Luís António de Oliveira Mendes intende [...] está ainda infinitamente distante de uma atitude abolicionista, e tem mesmo características de seu contrário”. ${ }^{69}$ Ou seja, o advogado baiano teria sido um escravista escondido por detrás de uma máscara humanista. Não por acaso, a versão do Discurso acadêmico que Capela teve em mãos e editou é aquela depurada de suas partes mais críticas à escravidão. ${ }^{70}$ Todavia, em qualquer das variantes consultadas, o que se observa é a denúncia geral das crueldades a que estavam submetidos os escravos, desde a hora em que eram capturados na África e, depois, no tráfico negreiro e nas fazendas brasileiras a que se destinavam.

Em certo sentido, Oliveira Mendes é herdeiro e continuador do Ethiope resgatado, do padre Ribeiro Rocha, como se percebe pelas frequentes súplicas à consciência cristã dos traficantes e proprietários. ${ }^{71}$ Porém, ele ultrapassou a simples denúncia motivada por sentimentos religiosos e humanitários para entrar abertamente na defesa da extinção do tráfico e, progressivamente, da escravidão, em sintonia com o pensamento antiescravista próprio do Iluminismo. Lembremos, entretanto, que as posições em prol do fim da escravidão não eram unânimes entre a intelectualidade luso-brasileira. Para alguns, a questão se colocava apenas como administração racional do plantel, como no caso do médico e naturalista

68 Antônio Penalves Rocha, "Ideias antiescravistas da Ilustração na sociedade escravista brasileira”, Revista Brasileira de História, v. 20, n. 39 (2000), pp. 37-68.

69 José Capela, "Prefácio” in Luís Antônio de Oliveira Mendes, Memória a respeito dos escravos e tráfico da escravatura entre a costa d'África e o Brazil: apresentada à Real Academia de Ciências de Lisboa, 1793, Porto: Escorpião, 1977, p. 14.

70 Capela foi pioneiro na difusão acadêmica do tratado de Oliveira Mendes, todavia escreveu a respeito num momento de radicalização política da historiografia de Portugal e do Brasil. Foi Capela quem me apresentou a Oliveira Mendes, no final dos anos 1970.

71 Manuel Ribeiro Rocha, Ethiope resgatado, empenhado, sustentado, corregido, instruído, e libertado, Lisboa: Francisco Luiz Ameno, 1758. 
Manuel Arruda da Câmara, senhor de escravos em Pernambuco, que, para obter aumento da produtividade, advogava o equilíbrio entre punição e emulação. ${ }^{72}$ Mais radical era o bispo e economista Azeredo Coutinho, contemporâneo de Mendes em Coimbra e seu parceiro na Academia, que defendia a legitimidade do tráfico e contestava os que condenavam a escravização de africanos em nome do direito natural. Interessante reter, para ter em vistas a dubiedade da Academia e da Coroa em relação ao tema, que Azeredo Coutinho também foi censurado. ${ }^{73}$ A primeira edição de sua obra foi impressa no estrangeiro e a segunda, sob os auspícios dos invasores franceses, o que lhe trouxe alguns problemas em sua trajetória acadêmica e eclesiástica. ${ }^{74}$ Não é ocioso lembrar que Oliveira Mendes deve ter estado presente na Academia quando Azeredo leu suas memórias em defesa da escravidão africana. Pode-se assim imaginar que os estudos de ambos representam um debate entre os dois acadêmicos.

Ao comentarem o Discurso acadêmico sobre as enfermidades que acometiam os cativos, os historiadores Godoy e Pereira já haviam assinalado que "se há uma diferença essencial entre as duas versões do texto, ela é verificada em seus últimos parágrafos”, nos quais o autor apresenta uma proposta de "lei municipal” e que foi suprimida na edição censurada. ${ }^{75}$ Ele tinha consciência de que suas proposições levavam-no a um terreno movediço: "Esta Real Academia, assim como o público, me há de perdoar ter transgredido os limites de Escritor, confundindo estes ofícios com os de Legislador; porém eles podem ter um disfarce bem

72 Manuel Arruda da Câmara, Memoria sobre a cultura dos algodoeiros, Lisboa: Casa Literária do Arco do Cego, 1799.

73 Guilherme Pereira das Neves, "Guardar mais silêncio do que falar: Azeredo Coutinho, Ribeiro dos Santos e a escravidão” in José Luís Cardoso (coord.), Economia política e os dilemas do Império luso-brasileiro (Lisboa: CNPCDP, 2001).

74 José Joaquim de Azeredo Coutinho, Analyse sur la justice du Commerce du rachat des esclaves de la côte d'Afrique, London: Baylis, 1798; José Joaquim de Azeredo Coutinho, Concordancia das leis de Portugal e das Bullas pontificias, das quaes humas permittem a escravidão dos pretos d'Africa, e outras prohibem a escravidão dos indios do Brazil, Lisboa: João Rodrigues Neves, 1808.

75 Godoy e Pereira, “A questão do tráfico de escravos”, pp. 2517-2522. 
aceito, quando tem por pequeno Reino o curto e limitado espaço de um gabinete particular" ${ }^{76}$

Seu código municipal, diga-se regional, era voltado especificamente às colônias americanas e tinha o objetivo explícito de eliminar gradualmente a escravização dos africanos. Se a necessidade impedia a abolição imediata, era preciso criar um sistema de redução do tráfico da escravaria fazendo com que "da mesma África por hora venha a menor porção dela que puder vir e que para o futuro dilatando-se pela observação o mesmo sistema, se levantem as mãos aos Céus, louvando a Onipotência de Deus, que por um destino feliz fez desterrar e desaparecer para sempre a escravidão dos pretos a todos odiosa". ${ }^{77}$

A primeira norma por ele proposta era acabar progressivamente com a perpetuidade e a hereditariedade do cativeiro, limitando-a a dez anos da "vida civil" dos escravos. Creio que nesse aspecto, Oliveira Mendes incorporou uma das noções básicas defendidas por Manuel Ribeiro Rocha. O Ethiope não poderia ser possuído, mas apenas "empenhado". A escravidão deveria ser necessariamente um estado provisório e, assim que o cativo tivesse condições para comprar sua alforria, ela aconteceria automaticamente. De certa forma, esta era uma condição muito corrente na própria África: a venda do corpo ou escravização por dívidas. ${ }^{78} \mathrm{O}$ padre Ribeiro Rocha reconhecia a validade jurídica do "resgate”, ou seja, a de que eram legítimos os meios usados para a escravização na África e partia do princípio de que cativos resgatados estavam sendo levados para uma condição muito melhor na América, do ponto de vista civilizacional, aí incluída a cristianização. Neste ponto, o pensamento de Oliveira Mendes era mais radical, pois ele tinha dúvidas sobre a legalidade e as vantagens do resgate para os africanos, como defenderam diversos autores que o

76 Mendes, "Discurso acadêmico ao programa”, p. 82.

77 Mendes, "Discurso acadêmico ao programa”, p. 78.

78 Sobre a percepção que os luso-brasileiros tinham do fenômeno, ver Magnus Roberto de Mello Pereira, "Brasileiros a serviço do Império: a África vista por naturais do Brasil, no século XVIII”, Revista Portuguesa de História, v. 1, t. 33 (1999), pp. 153-190 e pp. 170-172. 
antecederam e sucederam. ${ }^{79}$ No mais, o seu Etiophe também deveria ser "sustentado, corrigido, instruído e libertado". Uma das principais diferenças entre ambos residia no período máximo de escravização: dez anos para o acadêmico baiano, vinte anos para o padre. ${ }^{80}$ Oliveira Mendes preconizava ainda um sistema em que os cativos formariam uma espécie de poupança para a manumissão, guardada pelo senhor "como em um cofre”.

A segunda parte do código antiescravista deveria determinar que quando o senhor tratasse o escravo "com tiranias, matando-o à fome, não lhe dando o preciso vestuário, não o curando nas enfermidades e procedendo indiscretamente, sem causa a açoites”, este ganharia direito à liberdade.

A quarta proposição é particularmente interessante, uma vez que aborda uma questão que, por muito tempo, foi negligenciada por nossa historiografia: a família escrava. ${ }^{81}$ Oliveira Mendes propunha a determinação de que escravos e escravas casados que tivessem quatro filhos receberiam alforria automática, ou seja que os proprietários, dessa forma, seriam indenizados na proporção de dois para um, equivalendo os filhos ao preço dos genitores. A criação da prole caberia aos pais e estes só seriam escravizados a partir dos dezoito anos. Essa proposta de lei acompanhava a tradição cristã de reprovação dos maus-tratos a que estavam sujeitos os escravos defendida por autores como Antonil, Bensci e Ribeiro Rocha. ${ }^{82}$ A diferença é que, nesse aspecto, o preceito de Oliveira Mendes não se inclui propriamente na tradição de defesa da família, ainda que escrava,

79 Ver, por exemplo, João Severiano Maciel da Costa, Memória sobre a necessidade de abolir a introdução dos escravos africanos no Brasil, Coimbra: Imprensa da Universidade, 1821, pp. 11-14.

80 Rocha, Ethiope resgatado, p. 99.

81 Para um primeiro balanço historiográfico sobre o tema da família escrava, consultar Robert W. Slenes e Sheila de Castro Faria, "Família escrava e trabalho”, Tempo, v. 3, n. 6 (1998), pp. 1-7. Ver também Manolo Florentino e José Roberto de Góes, A paz nas senzalas, Rio de Janeiro: Civilização Brasileira, 1997.

82 André João Antonil, Cultura, e opulencia do Brasil por suas drogas, e minas, Lisboa: Deslandesiana, 1711; Jorge Benci, Economia cristã dos senhores no governo dos escravos, São Paulo: Grijalbo, 1977 [1700]. 
em nome da moral cristã. A despreocupação com desígnios dessa natureza revela-se no quinto capítulo de suas propostas, que se destinava a garantir a libertação da escrava que "provasse estar na mancebia com o senhor”, medida extensiva aos filhos nascidos dessa relação.

Na legislação sugerida pelo autor, a família escrava e os amancebamentos aparecem antes como constatação das relações sociais correntes na colônia e ele não demonstra estar escandalizado nem se propõe a corrigi-las, mas utilizá-las para o propósito maior, expresso no terceiro e no sexto capítulos de seu projeto, que é a criação de um mercado de trabalho livre, em cujo processo de estruturação a alforria dos cativos desempenharia o papel central.

Assim, o terceiro capítulo da lei previa o retorno à condição escrava daqueles libertos que não comprovassem que estavam ocupados após um ano e meio da manumissão. Mendes partia do princípio que o assalariamento seria vantajoso para ambas as partes. Para o patrão, o assalariamento da força de trabalho escrava deixaria de implicar em imobilização de capital, em custos de manutenção da mão de obra e no risco desse mesmo capital por morte dos cativos. ${ }^{83}$ Estes, por sua vez, ganhavam sua liberdade. Nas palavras de Oliveira Mendes, "o preto servil vestia-se e curava-se à custa do seu ordenado e despedia-se de seu amo quando bem o não tratasse e não o sustentasse: o amo muito mais lucrava, porque primeiro não empatava o fundo e o capital do escravo e não corra o risco do fôlego". ${ }^{84}$

O sexto capítulo da lei tratava de incentivar ainda mais a "propagação dos pretos livres”. Os alforriados que tivessem dez filhos receberiam como recompensa um dos reconvertidos à condição de escravidão por ociosidade.

Quando afirma que os forros "são os lenocistas, os aliciadores das filhas famílias; são os roubadores para sustentar os vícios; são os matadores para sustentar o capricho e a presunção”, Mendes faz coro com a noção

83 São raciocínios derivados de autores como Adam Smith e que condenavam o uso de mão de obra escrava sob o ponto de vista de uma suposta irracionalidade econômica.

84 Risco de fôlego é o risco de perda do escravo por morte deste. 
corrente entre a elite escravista da época, para quem os libertos eram, antes de tudo, libertinos que se dedicavam ao crime e à luxúria. ${ }^{85}$ Assim, seu projeto destinava-se não apenas a emancipar a sociedade das relações escravistas, mas impedir a formação de uma camada de “desocupados”. Em suas cartas ao Conde da Barca ele menciona repetidamente a questão. No limite, Oliveira Mendes propunha que na base da estrutura social das colônias portuguesas na América estivessem as famílias de "homens pretos livres”. A alforria sistemática, o estímulo à natalidade e a repressão ao ócio possibilitariam que, em alguns anos, as relações escravistas de trabalho e o tráfico deixassem de ser necessários.

Pode parecer pouco, mas há um avanço em relação aos demais intelectuais brasileiros de finais do século XVIII e início do XIX que se posicionaram contra o tráfico de escravos. Em primeiro lugar, porque Oliveira Mendes foi um crítico muito mais firme da crueldade que imperava em todo o processo de escravização iniciado na África, durante a travessia e no Brasil. ${ }^{86}$ Embora o autor também usasse algumas premissas embasadas nas vantagens econômicas do assalariamento, herdados da economia política, o forte de seus argumentos é de origem humanitária, humanística e religiosa. A escravidão atentava contra o direito natural e as leis divinas.

Houve, inclusive, um autor contemporâneo de Oliveira Mendes que estabeleceu uma espécie de debate com ele, ainda que a réplica tenha dormitado inédita até ser publicada em 1837. O militar baiano Domingos Alves Branco Moniz Barreto escreveu uma Memória sobre a abolição

85 Mendes, "Discurso acadêmico ao programa”, p. 80.

86 Sobre a questão, ver Alisson Eugênio, “As propostas de Luiz Antônio de Oliveira Mendes para reformar a escravidão apresentadas em sua memória sobre os escravos e tráfico de escravatura entre a costa da África e o Brasil (1793)”, Revista Espaço Plural, v. 14, n. 28 (2013), pp. 143-174; Alisson Eugênio, “Os relatos de Luiz Antônio de Oliveira Mendes sobre a saúde da população escrava: do trafico na África ao cativeiro no Brasil (1793)”, Ideias, v. 4 (2013), pp. 201-231; Rafael de Bivar Marquese, Feitores do corpo, missionários da mente, São Paulo, Companhia das Letras, 2004; Leila Mezan Algranti, Brasil: colonização e escravidão, Rio de Janeiro: Nova Fronteira, 2000. 
do comércio da escravatura na qual faz diversas referências à memória correlata de autoria de Mendes, mas sem referenciá-lo nominalmente. ${ }^{87}$ Tudo indica que a Memória sobre a abolição foi escrita entre 1812 e 1816, período em que o autor vivia no Rio de Janeiro. Um detalhe importante é que Moniz Barreto leu a versão mais espinhosa do texto do advogado, uma vez que menciona a "lei municipal” por ele proposta e que só aparece nessa edição. Disso se deduz que, de alguma maneira ainda obscura, circularam as duas versões da Memória de Oliveira Mendes, inclusive no Brasil.

Barreto se apropriou do texto do advogado, por vezes copiando trechos inteiros, para apresentar noções sobre os sistemas legais vigentes na África através dos quais eram "produzidos" os escravos. Todavia, inversamente ao que fizera Mendes, ele conclui pela legitimidade do sistema e da escravidão.

Do que se vem a tirar por conclusão que o Comércio da Escravatura é lícito, não só por que não é feito em pirataria e força armada e sim por convenção e à avença dos mesmos Potentados Africanos; mas porque até disso lhes resulta melhoramento e proveito e a maior felicidade. $1^{\circ}$ Porque aqueles Gentios vêm entrar no centro do Cristianismo e da verdadeira Religião, bem que esse não seja o verdadeiro objeto, que fomenta aquele Comércio. $2^{\circ}$ Porque com este resgate se evita a imensa mortandade que aqueles miseráveis Povos sofriam, principalmente em Guiné, em que também se incluíam os prisioneiros de guerra; cujo resgate uma vez que venha a cessar eles tornarão ao antigo uso dos seus infames e tiranos sacrifícios. ${ }^{88}$

São os mesmos pisados argumentos que deram suporte ético, moral, legal e religioso à escravidão e que ainda continuavam a ser defendidos

87 Domingos Alves Branco Moniz Barreto, Memória sobre a abolição do comércio da escravatura, Rio de Janeiro: F. de Paula Brito, 1837.

88 Barreto, Memória sobre a abolição, p. 20. 
por autores como Azeredo Coutinho, a quem Moniz Barreto recorreu explicitamente, ou por João Severiano Maciel da Costa, o Marquês de Queluz. ${ }^{89}$ Este último autor, que também foi um defensor da extinção progressiva do tráfico, parece estar dialogando diretamente com Oliveira Mendes quando afirmou com boa dose de cinismo que "o comércio dos escravos, conquanto contrário à humanidade, não é tão horrível como o figuram os seus antagonistas” uma vez que os cativos eram tirados da barbárie homicida africana e "transplantados de seus areais ardentes para o belo clima do Brasil e aí empregados no suave trabalho da agricultura" ${ }^{90}$

Moniz Barreto também concordava com a proposta da gradual extinção do comércio da escravatura africana e, para tanto, retomou uma série de propostas de Mendes. Na prática, ele se propunha a elaborar uma "lei municipal” concorrente à do advogado. Sim! Era preciso atalhar a tirania dos senhores, mas sem afrouxar a obediência. Não concordava que os escravos ganhassem a liberdade após dez anos de serviço, “como alguns escritores têm pretendido”, referindo-se a Oliveira Mendes, mas que a alforria fosse obrigatória quando o escravo tivesse meios de pagar por ela. Assentia também que os cativos que recebessem maus tratos fossem legalmente manumitidos e que as escravas amancebadas com seus senhores e os filhos nascidos dessas uniões fossem libertos. Barreto propunha que os escravos que dessem seis filhos aos senhores fossem alforriados. Para Mendes, bastavam quatro. Nas propostas de ambos, os que tivessem dez filhos receberiam algum tipo de benefício.

O militar baiano, assim como outros autores considerados “abolicionistas”, tais como Maciel da Costa, Gonçalves Chaves e Soares Franco não esboçaram o mais leve plano sobre o processo de integração dos ex-escravos. ${ }^{91}$ Limitaram-se quase sempre a defender a superioridade

89 Coutinho, Concordancia das leis de Portugal, p. 13.

90 Costa, Memória sobre a necessidade, p. 11.

91 Antônio José Gonçalves Chaves, Memórias econômo-políticas sobre a administração pública do Brasil, Porto Alegre: Erus, 1978 [1822]; Francisco Soares Franco, Ensaio sobre os Melhoramentos de Portugal e do Brasil, v. 4, Lisboa: Imprensa Nacional, 1821. 
econômica do uso da mão de obra livre em oposição ao da escrava e os benefícios sociais e políticos que adviriam da superação da escravidão. ${ }^{92}$ Apenas José Bonifácio de Andrada e Silva foi um pouco além e sugeriu que eles poderiam vir a ser arrendatários de "pequenas porções de terras descobertas ou taperas que hoje nada valem". ${ }^{93}$ Pode-se supor que as propostas de Oliveira Mendes iam na mesma direção, mas ele ultrapassa em muito Andrada e Silva. A crítica sistemática que fez à estrutura fundiária do Brasil e suas concepções raciais menos preconceituosas levaram-no a pensar, como já vimos, num processo de criação de um campesinato a partir da população já existente no Brasil, majoritariamente mestiça e oriunda da escravização de indígenas e africanos.

\section{De volta à Bahia}

Em 1810, Oliveira Mendes iniciou os preparativos para retornar à Bahia. No seu pedido de passaporte, dizia que precisava tomar conta dos bens que lhe couberam por herança de sua avó materna, dos tios e dos pais que estavam sob os cuidados de um tio já velho. ${ }^{94}$ Aparentemente, boa parte desses bens foram subtraídos por esse mesmo tio, o padre João Lobato de Almeida. A perda de parte da herança deve ter significado um pesado revés econômico para a família, agravado à época da invasão francesa, o que pode ter motivado seu retorno ao Brasil. A viagem de regresso teve início no final de 1811. Após 39 dias de travessia, a bordo do navio Santo Estevão, o bacharel e a família chegaram à Cidade da Bahia - era 3 de janeiro de $1812 .^{95}$

92 Rocha, Ideias antiescravistas, pp. 61-62.

93 José Bonifácio de Andrada e Silva, Representação à Assembleia Geral Constituinte e Legislativa do Império do Brasil sobre a escravatura, Paris: Firmin-Didot, 1825. p. 18.

94 AHU, Bahia ACL CU 005, cx. 219, doc. 15362, Requerimento de Luis Antônio de Oliveira Mendes ao príncipe regente solicitando passaporte para a Bahia, Lisboa, s. d.

95 Idade D’Ouro do Brasil, Salvador, n. 19, 6 mar. 1812. 
Mal desembarcou em Salvador, o bacharel incorporou Dias Lobato à sua assinatura e começou a empreender esforços para se integrar à vida intelectual da localidade. Usou um expediente bastante moderno para se apresentar à cidade. Deu a conhecer suas obras anunciando-as no jornal Idade D’Ouro do Brasil, o primeiro periódico impresso na colônia (Figura 2).

Figura 2

Anúncio publicado no jornal Idade d'Ouro do Brasil

Num. rg.

I D A DE

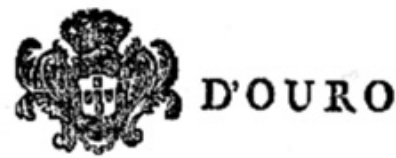

D O B R A Z I L.

Sexta feira 6 de Marfo de 1812

Luiz Antonio de Oliveira Mendes Dias Lobato, Adrogıdo da Casa da Sup plicaçío da Cidade de Lisboa, da Relaçáo Ecclesiasticı, da Nunciatura, e Caman Patriarchal, Socio da Real Academia das Sciencias de Lisboa, ace tualmente Advogado na Cidade da Bahia annuncis so Páblico as obras de suz composiçio, que se offerecens á venda em a Loja da Gazets, e promere his dando áluz as mais obras inedras, que annuncia o Caralogo dellas, que c :re impreaso, assim como as mais obras periodicas, que ss destina compot.

Tentativas, en que tem entrado o A . . . . . - - 160

Verdade vitrajada, e triumphante com sua estampa - - - - - 320

Mermotia da Maquina de fíataçio, e contraḉ̧o com sua estempa - - ;:0 Preliminares de Estatutos da augurada Sociedade dos Homens de letras da

Cidade da Bahis ................. 400

Caralogo das obras editas, e inediras do A. ....... 100

Entre as obras postas à venda estava um opúsculo intitulado Preliminares para o Estatuto da Real Sociedade Bahiense dos Homens de Letras. ${ }^{96}$ Junto com os planos de deixar Lisboa, Oliveira Mendes começou a arquitetar a instalação de uma instituição congênere da Academia Real das Ciências em Salvador, que congregaria os letrados da capitania e do restante do Brasil, entretanto, a proposta não foi aprovada pela Coroa. ${ }^{97}$

96 Não foi possível encontrar nenhum exemplar desta publicação para saber se o autor introduziu algum tipo de modificação em relação ao manuscrito apresentado à Academia das Ciências.

97 Apesar de a proposta ser amplamente conhecida, ela raramente é discutida pela historiografia brasileira. Ver Fabiana de Santana Andrade, “O Estatuto da real sociedade 
As fontes disponíveis não nos dão maiores pistas sobre a vida do advogado após seu retorno ao Brasil, mas parece que não foi das mais exitosas. O insucesso da proposta de fundar uma academia científica na Bahia não foi seu único fracasso. Falharam, também, todas as suas tentativas de conseguir uma magistratura na capitania. Dias Lobato fez sucessivas gestões para alcançar “os Lugares de letras de Juiz de Órfãos da Cidade da Bahia, de Juiz de Fora da Vila de Santo Amaro da Purificação e da Vila de Maragogipe na Comarca da Bahia”. Pleiteou também uma “beca honorária na Relação da Bahia, ou do Maranhão”, alegando as grandes perdas por “ocasião da invasão dos Franceses” que teriam provocado seu regresso. ${ }^{98}$

$\mathrm{Na}$ conjuntura da revolta dos escravos de 1814, sugeriu sem sucesso a criação de uma Intendência de Polícia na Bahia, nos moldes das de Lisboa e Porto, especialmente para atender às suas pretensões.

Parecia haver necessidade de se criar em a dita Cidade da Bahia o Lugar de Intendente da Polícia, à imitação da Cidade do Porto, cujo Magistrado com a moderação precisa se haja de entregar aos diversos ramos e aos importantíssimos objetos da mesma Polícia, de cuja falta bem poderão insurgir na ociosidade funestas consequências, ao que de profissão sistematicamente se não pode entregar a ouvidoria do Crime, que se acha onerada com negócios e deveres de igual ponderação, do que se segue relaxação, desejando o suplicante quanto possa, empregar-se no Real Serviço e do Público..$^{99}$

baiense dos homens de letras em 1810: o controle sobre a circulação de ideias no Brasil colonial”, Temporalidades, v. 6, n. 2 (2014), pp. 61-74.

98 BNB, C-0500, 035 n. 001-002, Requerimento de Luís Antônio de Oliveira Mendes solicitando um dos seguinte cargos: juiz de órfãos na cidade da Bahia, juiz de fora na Vila de Santo Amaro da Purificação ou na Vila de Margogipe, Salvador, [ca. 1817].

99 BNB, C-0500, 035 n. 001-002, Requerimento encaminhado por Luís Antônio de Oliveira Mendes ao Ministério do Império solicitando ser nomeado Intendente da Polícia da cidade da Bahia, Salvador, [ca. 1817]. 
Em carta a António de Araújo e Azevedo, o futuro Conde da Barca, Mendes argumentava que a revolta se dera por dois motivos. O primeiro era a "vadiação, e ociosidade de infinitos negros forros, e de muitos fugitivos a seus Senhores, da demasiada relaxação, em que eles se achavam nos abandonos da escravidão”. Quanto a isso, ele fazia coro com a elite baiana que se queixava à Coroa que o Conde dos Arcos, então governador da Bahia, era pouco severo com a escravaria. Seu ponto de vista, no entanto, não coincidia com o dessa mesma elite. A segunda causa da revolta dos escravos era a "indizível severidade, crueldade e tirania que para com eles obstinadamente praticavam seus senhores, o que desde longe já prometia funestos fins”. Dizia a seguir que:

Fiz pôr na Augusta Presença de S. A. R., quanto instava a necessidade Pública pela criação dessa nova Magistratura, que recaísse em pessoa hábil, prática, inteligente, e senhoriada do costume dos Povos, que com prudência de profissão se empregasse, sem distração, neste detalhe, para que com brandura e docilidade, sem sacrifícios os coibisse e fosse privativo conhecedor da causa pia do homem escravo e das queixas a barbaridades dos Senhores, que como homens, entregues às paixões e a barbaridades, eram proprietários e ao mesmo tempo Juízes e severos executores de suas mesmas sentenças, fazendo cárceres privados, torturas e tiranias, muito a seu arbítrio, fora da vindita pública, o que tudo é repugnante ao Direito, do que só se tira o ódio, e a reversão do rancor, e depois destas prevenções salutares, concluía como se adivinhasse futuros acasos, /tanta força tem verdadeiras premissas/, que toda demora e falta de providências era danosa e de funestas consequências, como assim em breve acontecerá por desgraça nossa.

Ou seja, a pessoa mais indicada para o cargo era ele próprio. Lembrava que já havia tratado disso, muitos anos antes, em sua monografia premiada pela Real Academia das Ciências, demonstrando que seu 
envolvimento com o tema da escravidão era antigo e não uma tentativa de se aproveitar oportunisticamente da conturbação do momento.

Certifico a V. Ex.a, autorizando-me com os anos decorridos, que nos prelúdios destes infelizes sucessos, em 1793, sem nenhumas esperanças de vir ter a minha casa do Brasil, o que fiz na resorte dos tempos com toda minha família já em Lisboa escrevera, em matéria uma Memória [...] premiada pela Academia Real das Ciências. ${ }^{100}$

Na mesma carta, voltava abertamente ao tema da barbárie dos senhores de escravos, o que reforça a suspeita de que o texto de seu Discurso acadêmico sobre as doenças de escravos, publicado pela Academia das Ciências, havia sido censurado e modificado pela instituição sem sua anuência e participação. Seus raciocínios sobre a escravidão retomavam o par de argumentos que envolvia a crueldade dos senhores e a ociosidade dos libertos, tal como na proposta de "lei municipal” inclusa na versão extensa da memória. O plano de criar uma Intendência da Polícia, enviado anteriormente ao Marques de Aguiar, e ao seu poderoso primo José Egídio Álvares de Almeida, o futuro Marquês de Santo Amaro, insistia nessas questões.

As revoltas dos escravos na Bahia reacenderam o pavor provocado pela revolução em São Domingos. Desde então, a rejeição ao tráfico ganhou novos argumentos: o excesso de escravos, ou de população negra, era um perigo para o Estado, diga-se, para a elite escravista. A ameaça representada pelo desequilíbrio entre populações negras e brancas passou a ser um argumento desenvolvido por diversos autores da época, como Maciel da Costa, Gonçalves Chaves e Soares Franco. ${ }^{101}$ Para quase todos esses letrados, o suposto antiescravismo confundia-se com racismo.

100 ADB, FAM/FAA-AAA/000887, Cota atual B-11 (18, 1), Carta ao Conde da Barca sugerindo a criação de uma Intendência Geral da Polícia em Salvador e se oferecendo para ocupar o cargo de Intendente, Salvador, 2 abr. 1814. p. 2.

101 Costa, Memória sobre a necessidade, pp. 19-37; Chaves, Memórias econômo-políticas, p. 40; Franco, Ensaio sobre os Melhoramentos, p. 8. 
Não é o caso de Oliveira Mendes, que não refluiu em relação a suas antigas propostas de estabelecer um colonato com base no homem negro livre.

Os seguidos insucessos após o retorno ao Brasil devem ter levado Oliveira Mendes a uma fase de desalento que só seria quebrada quando as Cortes Vintistas instigaram os "bons cidadãos” a remeterem “algumas Memorias interessantes à Nação, e ao Bem Comum da Pátria”. ${ }^{102}$ Tal como sempre reagira aos editais da Academia Real das Ciências, Oliveira Mendes não se furtou a contribuir e elaborou três memórias. Pelo menos duas delas foram remetidas às Cortes, em Portugal.

Na primeira, datada de 1821, ele voltava ao propósito de fundar em Salvador uma academia das ciências nos moldes da que frequentara em Lisboa. ${ }^{103}$ De novidade, a alteração do nome de Sociedade Bahiense dos Homens de Letras para Nova Athenas no Continente do Brasil. $\mathrm{Na}$ sequência, remeteu às Cortes uma memória na qual propunha a Reforma do Foro Judicial Lusitano-brasílico, retomando alguns dos temas desenvolvidos em seu ensaio sobre as enfermidades dos escravos. ${ }^{104}$ Nessa memória ele aproxima e funde uma série de temas que lhe eram caros: o controle da crueldade dos senhores de escravos, a condenação da escravidão perpétua, a crítica ao regime fundiário e o desenvolvimento de uma proposta de distribuição de terras.

O que se observa desde logo na proposta de Reforma do Foro é que Oliveira Mendes sofreu forte influência de Pascoal de Melo Freire, de quem se dizia discípulo. ${ }^{105}$ No fulcro dos interesses desse professor e jurista, estava a modernização do direito criminal português, alinhando-o com as transformações que vinham ocorrendo no restante da Europa

102 Arquivo Histórico Parlamentar Português (AHP), Lisboa, Sec. I/II, cx. 46, maço 26, doc. 2, Carta de encaminhamento de memória sobre a criação da Nova Athenas na Cidade da Bahia, encaminhada às Cortes Gerais e Extraordinárias da Nação Portuguesa, Salvador, 8 nov. 1821.

103 Memória hoje desaparecida.

104 Memória da Reforma, 1821.

105 ACL, Série Azul, cód. 364, 365 e 366. 
devido, principalmente, ao impulso provocado pela publicação, em 1764, do tratado de Cesare Beccaria sobre os delitos e sua punição. ${ }^{106}$

Com referência ao Código de Direito Civil dos Romanos e suas penas atrozes, dizia Oliveira Mendes que deveria ser "dado o necessário desconto dos tempos escuros [...] em que ele fora compilado" ${ }^{107}$ Considerava que mais bárbara ainda era a permanência de punições cruéis no direito pátrio. Continuar a aplicar as penalidades inclementes previstas nos antigos códigos romanos e principalmente nas Ordenações do Reino era simplesmente inaceitável. "Naquele obdurecido e desgraçado Código Penal, a cada passo com franqueza se diz e se encontra $=$ morra per ela $=$ atanazar = cortar mãos em vida $=$ ser arrastado por cavalos $=$ dilacerado por eles $=$ queimados vivos $=$ esquartejado $=$ salgados os inocentes terrenos [...] até com fixação nos pórticos de quartos dos Humanos”. ${ }^{108}$ No Novo Mundo, a situação lhe parecia mais grave.

Em uma e outra página dele, os dois Mundos gemam! O Mundo Novo, por menos culto e incivilizado proporcionalmente chore na presença dos Verres, que são Verres, que com coração de ferro executam leis de ferro.

São ensaios da Tirania, da Crueldade, o que disse eu ensaios! São as tiranias e as crueldades mesmas em pessoa, = Prisões, entre estas muitas escuras, úmidas, subterrâneas masmorras, enxovias, estreitados e sombrios segredos, detenções esquecidas nos imundos e fedorentos cárceres, que, por constituídos nas segundas casas dos vastos domínios da prepotência altiva, sol não vê.

106 Cesare Beccaria, Dei delitti e delle pene, Livorno: Marco Coltellini, 1764.

107 Memória da Reforma, 1821, f. 13.

108 Memória da Reforma, 1821, f. 15. A lembrança das execuções espetaculosas do período pombalino e de outras mais recentes, como as de Joaquim José da Silva Xavier e de alguns dos envolvidos na Conjuração Baiana, deviam estar ainda bem vivas. 
A tanto se seguiram as aflitivas torturas, praticadas a arbítrio de hum vingativo Juiz, que deste modo mantido na soberba plantava despotismo, para se fazer, além de temível, mais respeitoso. ${ }^{109}$

Pior ainda era a situação dos cativos, sujeitos a um regime em que a ordem privada dos senhores confundia-se com a ordem pública.

No continente do Brasil, em ódio à Humanidade, por ser país de escravidão perpétua há um costume bem digno de desterro, que o senhorio de escravos de sangue frio com 160 r', que acompanha ao bilhete, mandam ao carcereiro, que nas grades da cadeia faça açoitar o escravo com certo número de açoites, fazendo dele executor da alta Justiça, ao que se segue grilhão aos pés, cepo às costas, correntes firmadas no sobrado, vira mundos, o cárcere privado do Tronco, donde são tirados, para as novenas e trezenas de açoites, o que no estado de reforma é digno de coibição. ${ }^{110}$

Na sequência de suas propostas, Oliveira Mendes entra no âmbito das Leis Agrárias que ele considerava que deveriam "ocupar um muito distinto lugar” no "Novo Código Nacional e Constitucional”. A formação essencialmente fisiocrata que recebera em Coimbra levava-o a reconhecer a agricultura como a mais nobre e essencial atividade humana e a principal fonte da riqueza das nações. Recriminava, em decorrência, a exploração a que estavam submetidos aqueles que labutavam diretamente na terra: "parece que Deus, Nosso Sumo Bem, mais amaldiçoa a Terra, pelas interpostas pessoas daqueles, que sem cavar nela, de contínuo estudam meios e modos de se utilizarem dos trabalhos dos outros e de quanto ela pode produzir". ${ }^{111}$

109 Memória da Reforma, 1821, f. 14v.

110 Memória da Reforma, 1821, ff. 14v-15.

111 Memória da Reforma, 1821, f. 31v. 
Como já mencionado, Oliveira Mendes reprovava in totum os regimes de propriedade agrícola adotados tanto em Portugal quanto nas colônias americanas. Sua crítica mais geral dirigia-se às doações régias de terras por meio do sistema de donatarias e sesmarias. Na opinião do autor, tais doações deveriam ser simplesmente extintas, especialmente pelo abuso das rendas que os senhores das terras cobravam dos agricultores.

Quanto ao Velho Mundo, como a Agricultura se acha encabeçada em possessórios dos particulares ou de Donatários, aqueles, de três em três anos (se a tanto chega), fazem acrescentar o preço da renda e bom seria, que em benefício da Agricultura e do trabalho do colono, se fizesse conservar, sem alteração alguma o antigo preço das medidas ou dos dinheiros das primeiras rendas. Estes mantidos nas suas Doações Régias, que de todo devem ser extintas, com mor respeito todos aqueles impostos, que são extorquidos e cobrados à força, por meio de violentos sequestros. $^{112}$

Na sequência, ele retoma as críticas ao regime de doação de sesmarias. Considerava que seu uso passava "longe dos fins para que elas foram concebidas" e que os sesmeiros formavam uma camada social de ociosos. ${ }^{113}$ Mendes, assim como muitos de seus parceiros formados em Coimbra, compartilhava das ideias de Adam Smith, entre as quais a de que o trabalho e não a propriedade da terra deveria ser a fonte da riqueza. Entre os luso-brasileiros, José da Silva Lisboa, o futuro Visconde de Cairu, foi o mais notável defensor de noções dessa natureza. ${ }^{114}$

À época, toda uma geração de advogados e juristas tecia críticas ao regime de propriedade agrária vigente, considerado uma sobrevivência

112 Memória da Reforma, 1821, f. 31v.

113 Memória da Reforma, 1821, f. 30v, nota de rodapé.

114 Para o Brasil, ver José Flávio Pereira e Lupércio Antônio Pereira, “Instituições jurídicas, propriedade fundiária e desenvolvimento econômico no pensamento de José da Silva Lisboa (1829)”, História, v. 25 (2006), pp. 192-213. p. 204; José da Silva Lisboa, Princípios de Economia Política, Rio de Janeiro: Irmãos Pongetti, 1956, p. 165. 
feudal. A instituição mais reprovada era a do encabeçamento de terras (os morgados, capelas etc.) que assegurava os direitos de primogenitura e impediam o parcelamento da propriedade fundiária. ${ }^{115}$ Muitos autores portugueses e brasileiros, a exemplo de Silva Lisboa, trataram a concentração de terras em termos de racionalidade ou irracionalidade econômica. Já as preocupações de Oliveira Mendes, quando defendia agricultores contra os proprietários, eram também de caráter social. O que fica evidente nas suas críticas aos regimes fundiários vigentes em Portugal. Todavia, a transposição dessas ideias para as colônias era complexa. O uso extensivo de mão de obra escrava na agricultura das colônias não era um detalhe que pudesse ser desprezado. Assim, não é ocioso perguntar ao autor quem era o "agricultor" a que se referia em suas memórias?

A existência de um campesinato no Brasil do período colonial é alvo de controvérsias na historiografia, desde 1942, quando Caio Prado Júnior abriu espaço para o estudo de pobres livres no campo e nas cidades. ${ }^{116}$ Ciro Flamarion Cardoso fez escola ao propor que teria existido uma "brecha camponesa” responsável pela produção da maior parte dos produtos alimentares. ${ }^{117}$ Mais recentemente, Maria Sylvia de Carvalho Franco e Maria Yedda Linhares, entre outros historiadores, procuraram mostrar que na economia colonial brasileira havia uma associação entre o latifúndio e os pequenos e médios produtores que atendiam o mercado das grandes propriedades e dos consumidores urbanos. ${ }^{118}$

115 No Brasil o encabeçamento só foi extinto em 1835 e em Portugal, em 1863. Para Portugal, ver Judite Maria Nunes Esteves, Do morgadio à divisão igualitária dos bens: extinção do morgadio e estratégias de perpetuação do poder familiar. Entre o fim do século XIX e o século $X X$, Tese (Doutorado em História), Universidade Nova de Lisboa, Lisboa, 2008.

116 Caio Prado Júnior, Formação do Brasil contemporâneo, São Paulo: Brasiliense, 1986, pp. 159-161.

117 Ciro Flamarion Cardoso, “A brecha camponesa no sistema escravista” in Agricultura, escravidão e capitalismo (Petrópolis: Vozes, 1979), pp. 133-154.

118 Maria Sylvia de Carvalho Franco, Homens livres na ordem escravocrata, São Paulo: EdUSP, 1969; Maria Yedda Linhares e Francisco Carlos Teixeira da Silva, “A questão da agricultura de subsistência” in História da agricultura brasileira: combates e controvérsias, São Paulo: Brasiliense, 1981. 
Oliveira Mendes usou as palavras agricultor e lavrador de forma bastante ambígua. Em seu texto sobre a economia da Bahia ele se refere com frequência a três categorias de agricultores: os proprietários de engenhos, os lavradores e os agricultores em geral. Quem eram os proprietários de engenho é evidente. Na categoria lavradores percebe-se que estavam incluídos os produtores de tabaco e os de cana que não possuíam engenhos. Já em relação aos agricultores em geral, pode-se presumir que fossem os produtores de alimentos, na condição de pequenos proprietários, arrendatários e colonos das grandes propriedades.

Sua inconformidade mais incisiva era contra a exploração daquelas três categorias formais de agricultores pelos comerciantes, que submetê-las-iam a uma dependência que forçava o "industrioso agricultor a trabalhar incessantemente para terceiro, e não para si”. ${ }^{119}$ Contudo, suas preocupações extrapolavam esses regimes fundiários formais para entrar no universo mais amplo dos despossuídos. Nenhuma novidade nisso. No período havia todo um ideário corrente de que as populações volantes, os quilombolas e os caboclos que viviam espalhados pelos imensos sertões brasileiros deveriam ser reduzidos à "sociedade civil”, para usar a expressão da época. Essa foi uma das grandes obsessões da política colonial pombalina. ${ }^{120}$ Uma carta régia, datada de 22 de julho de 1766, determinava que os governadores das diversas capitanias tomassem medidas para obrigar àqueles que viviam separados da "sociedade civil” e do "comércio humano" a morar nas proximidades das vilas e cidades ou se assalariarem em propriedades agrícolas estabelecidas. Prescrevia a ordem régia que:

119 Discurso preliminar, Lisboa, s. d., p. 35.

120 Sobre essas políticas pombalinas, ver Magnus Roberto de Mello Pereira, “Considerações sobre a ação urbanística do período pombalino”, Ágora, v. 1, n. 1 (1995), pp. 61-82; Antonio Cesar de Almeida Santos, "Para viverem juntos em povoações bem estabelecidas: um estudo sobre a política urbanística pombalina”, Tese (Doutorado em História), Universidade Federal do Paraná, Curitiba, 1999. 
todos os homens que nos ditos sertões se acharem vagabundos ou em sítios volantes sejam logo obrigados a escolherem lugares acomodados para viverem junto a Povoações civis que pelo menos tenham cinquenta fogos pera cima com Juiz ordinário vereadores e procuradores do Conselho, repartindo-se, entre eles com justa proporção os terrenos adjacentes. ${ }^{121}$

A eficácia de tais medidas está longe de ter sido estudada, mas tudo indica que foi nula. O próprio Vice-rei do Brasil, o Conde da Cunha, alegava que a proposta era inviável. ${ }^{122}$ Oliveira Mendes, décadas depois, insistia em planos de mesma natureza, tocando em um ponto sensível da questão. Perseverava na ideia de usar terras ociosas para promover uma incipiente "reforma agrária”. Uma das propostas que ele apresentou na Reforma do Foro Judicial era a criação de uma Inspetoria que, entre outras atribuições, seria responsável por tomar as terras não utilizadas por donatários e sesmeiros e reparti-las entre essa "população volante”.

Também por sua conta, em ereção de novos Lugares e Povoações, correrá o assentamento e o estabelecimento das pessoas pobres, necessitadas, vadias e degradadas, que pela Intendência da Polícia lhe forem dirigidas, formalizando casais, em beneficio da Civilização e da Agricultura, dando e repartindo com eles terras baldias das Sesmarias abandonadas, desprezadas e incultivadas, ou fazendo-se menores.

Contribuirá esse inspetor, incansável da agricultura, com os instrumentos agrários, e com o sustendo de 6 meses a esses infelizes felicitados, supridos pela folhas dos dízimos, que da terra e da mesma

121 Boletim do Archivo Municipal de Curitiba, v. 16, p. 36.

122 AHU, Rio de Janeiro CU 017, cx. 80, doc. 7.174. Ofício vice-rei do Estado do Brasil ao secretário de estado da Marinha e Ultramar informando o recolhimento de todos os vagabundos e delinqüentes dos sertões da capitania para assentá-los em vilas com mais de 50 fogos, referindo as dificuldades encontradas na aplicação de tal ordem, Rio de Janeiro, 23 fev. 1767. 
agricultura são tirados, nas expectativas de que outros muito maiores serão recebidos e prestados, sempre com aumento pelos novos Agrícolas e Colonos acrescidos. ${ }^{123}$

O autor não se contentou, no entanto, em reiterar e detalhar esse antigo plano. Acoplou-o a um dos seus temas de preferência: o da abolição progressiva da escravidão. Usou sua proposta de Reforma do Foro Judicial para dar continuidade a muitas das questões avançadas em seu texto mais conhecido, o Discurso acadêmico sobre as doenças que afligiam os africanos escravizados.

Como vimos, Mendes foi um defensor da abolição gradual, assim como muitos integrantes da intelectualidade brasileira do período. O pretexto usado para não radicalizar as propostas abolicionistas era o de que não seria possível nem aceitável desagregar o núcleo do sistema produtivo colonial português na América, ou seja, o latifúndio monocultor escravista. Para a intelectualidade luso-brasileira formada em Coimbra, o “poderoso império” português encontrava nesse sistema o seu principal sustentáculo econômico e social. Daí o caráter protelatório, com que a abolição foi tratada. Mais tarde, quando a nação brasileira independente começou a ser concebida concreta e conceitualmente, esse paradigma foi mantido.

Oliveira Mendes, no entanto, avançava em algumas questões. Embora, como vimos, alguns autores vejam nele um escravista disfarçado, ele condenou o cativeiro reiteradamente. Em seu horizonte estava a criação de um mercado de trabalho livre em que os libertos desempenhariam o principal papel, por meio do assalariamento compulsório, ou de sua transformação em campesinato. Assim, adiantou uma proposta de atualização das "leis municipais" que constavam no Discurso acadêmico sobre as causas das doenças dos escravos, de 1793. A questão da manumissão da

123 Memória da Reforma, 1821, ff. 126v-127. 
escravatura ainda ocupava lugar central em seus projetos e, em decorrência, insistia na condenação da escravidão perpétua.

Que o Escravo de bom proceder, que por 20 anos bem servir, sucedendo-lhe as obras ao preço, já com o desconto de todas pequenas despesas feitas, fique manumitido, sendo admitido com a cláusula específica e essencial na manumissão que ficará servindo ao antigo Snr, ou a outro qualquer, pelo preço de 200 r.' por dia, tudo para o extermínio das escravidões eternas e perpétuas, o que é em si bárbaro, e também para que aos poucos e insensivelmente se vá introduzindo que os pretos forros e manumitidos, assalariadamente entrem a servir a bem da extinção da desgraçada escravidão. ${ }^{124}$

Nesse ponto específico, percebe-se que houve um retrocesso. Nos quase trinta anos que separam a elaboração das duas memórias, o limite de dez anos para a escravização aumentou para vinte, tal como pregava o Ethiope Resgatado. ${ }^{125}$ No entanto, manteve a ideia de que deveriam ser dadas aos escravos as condições para que eles constituíssem um pecúlio para a compra da liberdade, que deveria ser automática para o cativo que conseguisse pagar o valor que lhe fosse atribuído. A supervisão das alforrias deixaria de caber aos proprietário, como sugeria a proposta antiga, para ser incluída nas competências do Inspetor Agrícola, elemento chave das leis agrárias propostas pelo autor.

Competirá e entrará na sua repartição, com extermínio de pleitos, como um dos capítulos da Lei Agrária, aquilo mesmo que já tem sido de alta consideração à Cortes, que o Escravo sendo estimado por árbitros recíprocos, dando o seu valor, seja logo pelo Inspetor Agricular manumitido, com extermínio perpétuo das eternas Escravidões, tão

124 Memória da Reforma, 1821, f. 126.

125 Rocha, Ethiope resgatado, p. 99. 
opostas à Natureza Humana, à Civilização dos Povos e ao que deve ser de bom, santo, religioso e político. ${ }^{126}$

Mantinha-se a proposta de que as escravas tomadas como mancebas por seus senhores deveriam receber pronta manumissão, bem como os filhos nascidos dessa relação. O mesmo deveria ocorrer com as escravas que tivessem dado a seus donos seis filhos, que "vingassem”.

\section{Oh! Pátria}

No pensamento jurídico de Oliveira Mendes, a predominância da agricultura escravista era responsável por conferir certas particularidades ao Brasil, as quais deveriam ter reflexos na legislação. Ele advogava a universalidade das leis em todo o império português, mas reconhecia que elas jamais poderiam dar conta das especificidades regionais. Leis feitas para condições europeias não seriam de todo aplicáveis às do Novo Mundo, a começar pelo impacto cultural resultante da composição da população da colônia.

Sendo os costumes pois no misto mais Africanos do que Europeus, e por isso costumes novos e em si diversíssimos, e estes coibidos e regidos por expressas e terminantes Leis, e essas que reinarem na Europa Lusa nunca jamais podem reinar e ser aplicadas a outro diverso País, clima e estação, em que tudo não só é diverso, mas também muitas vezes diametralmente oposto, e quando assim não seja, pelo menos variados, em último ponto na sua intenção e extensão. ${ }^{127}$

No entanto, ele não considerava que a origem dos habitantes era a responsável pelas mazelas da América portuguesa. Em suas concepções, a questão racial não tinha maior peso. Sim, os africanos eram atrasados

126 Memória da Reforma, 1821, f. 127.

127 Memória da Reforma, 1821, ff. 37-37v. 
sob uma perspectiva social e econômica, mas não o eram do ponto de vista racial. As luzes da civilização (cristã e ocidental) iriam tirá-los do obscurantismo em que supostamente viviam.

No momento em que escreveu a Reforma do Foro Judicial, a rejeição das populações não europeias pela elite luso-brasileira ainda não estava plenamente corporificada. A formulação da panaceia da atração de imigrantes vindos da Europa para resolver o pecado original da sociedade brasileira, a predominância de índios e negros, ainda dava apenas os seus primeiros passos. ${ }^{128}$ Assim, no julgamento do autor, a origem africana de grande parte da população brasileira era um dado e não um problema. A mácula social não era a negritude, mas a escravidão. O cativeiro perpétuo dos africanos e a má distribuição da terra eram os obstáculos a vencer. Libertos e mestiços eram a chave para a construção de um povo morigerado. Morigeração forçada, se necessário.

Ainda que de forma enviesada e confusa, Luís Antônio de Oliveira Mendes incluiu em seu último texto conhecido alguns elementos de um projeto de Brasil. Ele, que era essencialmente um autor que se dedicara a pensar o império colonial português, havia mudado suas "apetências" para privilegiar o município, o regional, o Brasil enfim. Conclamava a grande pátria portuguesa, questionando quais crimes cometia ao desenvolver propostas para o bem do Brasil e de seu domiciliário, a pátria chica baiana: “Oh! Pátria, nestas minhas apetências no Município, e no meu mesmo Domiciliário, nestes meus esforços, quais serão meus crimes? São os de escrever a bem e a favor da Pátria?”

No entanto, isso não deve ser tomado como indício de adesão a ideias de independência das colônias americanas. Nesse exato momento, Oliveira Mendes estava a rabiscar uma Memoria demonstrativa da reunião, da consolidação, da segurança e da defesa interna e externa

128 Já no final do período colonial, começaria a ser formulada uma política de substituição ou "melhoramento" da população, de fundo racial. Ver, por exemplo, ADB, FAM-FAA-AAA-G-004531-0001, José da Silva Lisboa, Parecer dado por ordem superior sobre os expedientes necessários ao progresso e melhoramento da população do Brazil, Rio de Janeiro, [ca. 1820]. 
das Províncias do Reino Unido. ${ }^{129} \mathrm{O}$ título indica que ele se propunha a avançar jurídica e conceitualmente em uma proposta de Reino Unido, quem sabe esboçando algum tipo de união federativa, como sugere a referência a "Províncias".

Recebido em 5 jun. 2020

Aprovado em 18 dez. 2020

doi: 10.9771/aa.v0i63.37161

129 Memória da Reforma, 1821, f. 22v. Não se conhece o paradeiro da tal memória, se é que Oliveira Mendes chegou a concluí-la. 
O presente artigo explora o ideário de Luís Antônio de Oliveira Mendes sobre um conjunto de temas referentes à escravidão e ao regime fundiário na transição do século XVIII para o XIX: o controle da crueldade dos senhores de escravos; a condenação da escravidão perpétua; e a distribuição de terras baldias entre libertos e outros despossuídos. Para entender esse ideário foi preciso compreender e localizar historicamente a origem familiar e o universo da formação intelectual de Oliveira Mendes, da qual fez parte a Universidade de Coimbra e a Academia Real das Ciências de Lisboa.

Escravidão | Antiescravismo | Distribuição de terras | Intelectualidade luso-brasileira

SLAVERY AND ACCESS to LAND

in Luís Antônio de Oliveira Mendes’ Views (1792-1821)

This article explores Luís Antônio de Oliveira Mendes' ideas about themes related to slavery and the land ownership regime at the turn of the 19th century: the control of the cruelty of slaveholders; the condemnation of perpetual slavery; and the distribution of unoccupied land to freed and other dispossessed people. In understanding Oliveira Mendes' ideas, it is necessary to comprehend and historically locate his family origin and of the intellectual formation of Oliveira Mendes, which included the University of Coimbra and the Royal Academy of Sciences in Lisbon.

Slavery | Anti-slavery | Land distribution | Luso-Brazilian intellectuals 